\title{
Identification and Characterization of Alternaria Species Associated with Moldy Core of Apple in Chile
}

Karina Elfar ${ }^{\dagger}$ Juan P. Zoffoli, and Bernardo A. Latorre, Facultad de Agronomía e Ingeniería Forestal, Pontificia Universidad Católica de Chile, Vicuña Mackenna 4860, Santiago, Chile

\begin{abstract}
Moldy core (MC) of apple is an important disease in Chile, with prevalence observed between 4 and $46 \%$ in Fuji, Oregon Spur Red Chief, and Scarlet apple in the 2014-15 and 2015-16 growing seasons. However, there is no information on the identity of the causal agents associated with $\mathrm{MC}$ in Chile. The analysis of $653 \mathrm{MC}$ fruit revealed the presence of several genera of filamentous fungi. However, species of Alternaria (67.7\%) were by far the most frequently fungi isolated. In total, 41 Alternaria isolates were characterized morphologically and molecularly using Alternaria major allergen Alt a1, calmodulin, and plasma membrane ATPase gene regions. Six small-spored Alternaria spp. were identified; namely, in order of importance, Alternaria tenuissima, A. arborescens, A. alternata, and A. dumosa in sect. Alternaria; A. frumenti in sect. Infectoriae;

and A. kordkuyana in sect. Pseudoalternaria. MC symptoms were reproducible and consisted of a light gray to dark olive-green mycelium over the carpel and seed of immature and mature fruit, confirming that the isolates of these Alternaria spp. were pathogenic. These isolates caused brown necrotic lesions with concentric rings on wounded detached apple leaves. This study demonstrated that at least six Alternaria spp. are the cause of MC of apple in Chile. These Alternaria spp. were isolated alone, or with two or more species coexisting in the same fruit. This is the first report of A. tenuissima, A. arborescens, A. frumenti, A. dumosa, and $A$. kordkuyana associated with $\mathrm{MC}$ of apple in Chile and the first report of A. frumenti, A. kordkuyana, and A. dumosa causing MC of apple worldwide.
\end{abstract}

Chile is one of the largest apple producers in the southern hemisphere, with more than 37,200 ha planted and a total production of approximately 765,000 tons in 2016 (https://www.odepa.gob.cl/). Moldy core and core rot are considered two important diseases in apple with an open sinus from the calyx to the core region (McLeod 2014). Core rot usually follows a moldy core condition. This study primarily focuses on moldy core, which considerably affects apple production in Chile. A disease prevalence between 4 and $29 \%$ was estimated in Oregon Spur (= Red King Oregon) apple at harvest in Chile late in the 1980s (Latorre 1986; Morales 1986). Recently, a moldy core prevalence between 4 and $46 \%$ was determined at harvest in new apple cultivars (Fuji, Red Chief, and Scarlet) planted in Chile. Similarly, prevalences varying from 5 to $12 \%$ have been reported in susceptible cultivars in Australia, Israel, and South Africa (Kupferman 1992; Reuveni 2006; Serdani et al. 1998). A moldy core prevalence exceeding 40\% was reported in Israel in 2003 (Reuveni 2006), and 38 to $65 \%$ of fruit with moldy core were estimated in Ohio in 1980 and 1981 (Ellis and Barrat 1983).

Moldy core infection occurs in the orchard but it can also occur in the packing house (Spotts et al. 1988). It is characterized by fungal mycelial growth that is restricted to the carpel without necessarily affecting the fruit flesh. Infected fruit ripen earlier, are often smaller and slightly deformed, and fall prematurely compared with healthy fruit (Latorre 1983; McLeod 2014; Niem et al. 2007). Because of the importance of moldy core, apple packing houses commonly estimate disease prevalence at the reception of each apple lot in Chile. Only those lots with no evidence of moldy core are kept in controlled atmosphere chambers.

${ }^{\dagger}$ Corresponding author: Karina Elfar; E-mail: kdelfar@uc.cl

Funding: Financial support was provided by Comisión Nacional de Investigación Científica y Tecnológica (CONICYT) project Beca Doctorado Number Folio 21141074 and CONICYT provided a scholarship to K. Elfar to pursue her postgraduate studies at the Pontificia Universidad Católica de Chile.

Accepted for publication 28 May 2018.

(C) 2018 The American Phytopathological Society
The open-sinus condition that characterizes most Red Delicious apple, unlike Granny Smith apple, can explain the relatively high susceptibility to moldy core exhibited by this cultivar (Pinilla et al. 1996; Serdani et al. 1998). However, other factors such as mesoderm $\mathrm{pH}$ and locule sensitivity to colonization can affect apple susceptibility to moldy core in open-sinus apple (Niem et al. 2007).

Species of Alternaria have been frequently associated with moldy core. (Ellis and Barrat 1983; McLeod 2014; Reuveni et al. 2002). However, other genera of filamentous fungi such as species of Aspergillus, Cladosporium, Coniothyrium, Epicoccum, Phoma, and Stemphylium have also been associated with this syndrome; nonetheless, species of Alternaria are the most frequently isolated fungi (Ellis and Barrat 1983; Gao et al. 2013; McLeod 2014; Serdani et al. 2002).

At least two small-spored Alternaria spp., Alternaria alternata and A. tenuissima, have been associated with moldy core of apple (McLeod 2014). Nevertheless, recent studies suggest that a complex of small-spored Alternaria spp., including A. alternata, A. arborescens, $A$. infectoria, and A. tenuissima, may be associated with moldy core of apple (Gao et al. 2013; Ntasiou et al. 2015). A similar situation has been reported for core rot in pomegranate (Luo et al. 2017; Michailides et al. 2008).

The identification of the small-spored species of the genus Alternaria based on taxonomic characteristics is challenging due to a high diversity and few characteristics that allow their unambiguous identification (Andrew et al. 2009). At present, molecular and phylogenetic analysis are essential for recognizing species within small-spored Alternaria spp. Different loci have been used, such as nuclear ribosomal DNA (rDNA), internal transcribed spacer (ITS) regions, mitochondrial small subunit, and many protein-coding genes (Andrew et al. 2009; Hong et al. 2005; Lawrence et al. 2013, 2016; Pryor and Gilbertson 2000; Woudenberg et al. 2013, 2015). A multilocus study was carried out by Lawrence et al. (2013), who showed that the most informative protein-coding genes to identify Alternaria spp., in order of importance, are plasma membrane ATPase (ATPase), calmodulin (CAL), Alternaria major allergen Alt a1 (Alt al), glyceraldehyde-3-phosphate dehydrogenase, and actin. However, ATPase and CAL have been suggested as the most appropriate markers for molecular identification within smallspored Alternaria spp. Other genes such as $\beta$-tubulin and translation elongation factor $1-\alpha$ were the least informative genes for the identification of Alternaria spp. (Lawrence et al. 2013, 2016). Furthermore, the histone 3 gene (HIS3) has been used to separate A. alternata from A. tenuissima (Rang et al. 2002; Sun and Huang 2017). 
In Chile, the etiology of moldy core remains to be determined, particularly for cultivars that are planted at present. Therefore, the objective of this work was to characterize and study the role of Alternaria spp. associated with moldy core of apple in Chile.

\section{Materials and Methods}

Sampling locations and fungal isolation. In total, 2,000 apparently healthy fruit of apple cultivars Fuji, Red Chief, Oregon Spur, and Scarlet, with open-sinus fruit, were sampled randomly from three commercial orchards located in Graneros $\left(34^{\circ} 0.40^{\prime}\right.$ latitude S), Río

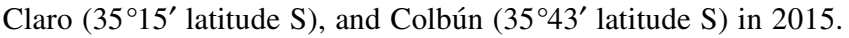
Eight additional orchards, between Pirque $\left(33^{\circ} 0.40^{\prime}\right.$ latitude $\left.S\right)$, and Traiguén $\left(38^{\circ} 0.34^{\prime}\right.$ latitude $\left.S\right)$, were surveyed in 2016 (Fig. 1). In addition, apparently healthy fruit $(n=200)$ of Granny Smith apple, with a closed sinus, were sampled in one orchard in Graneros. Fruit were sampled 2 to 3 weeks before harvest, transported to the laboratory, stored at $5^{\circ} \mathrm{C}$, and evaluated within 2 weeks. The apple fruit were washed under running tap water and surface disinfected ( $75 \%$ ethanol, $5 \mathrm{~min}$ ) before sectioning each fruit longitudinally. The carpels and flesh were examined and classified as healthy or diseased (Gao et al. 2013). The later fruit were classified as (i) brown core, with brown necrotic lesions of the carpel walls and absence of mycelium growth; (ii) moldy core (Fig. 2a), with carpels colonized by gray to dark olive-green mycelium; (iii) dry rot, with dry and corky brown rot of the flesh, in addition to the presence of mycelium in the carpels; or (iv) wet rot, with wet and soft brown rot of the flesh, in addition to mycelium growth in the carpels.

Isolations were attempted from small pieces ( 2 to $5 \mathrm{~mm}$ in length) of mesocarp (flesh), carpel walls, and seed on potato dextrose agar (PDA) acidified with $92 \%$ lactic acid at $0.5 \mathrm{ml} /$ liter (APDA) plus 0.1\% Igepal CO-630 (Sigma-Aldrich, St. Louis), which was used as a colony growth restrictor (Elfar et al. 2013). The cultures were incubated for 7 to 10 days at room temperature $\left(20\right.$ to $\left.22^{\circ} \mathrm{C}\right)$ in the dark prior to the determination of the total number of Alternaria-like colonies under a stereoscopic microscope. Fungal colonies were tentatively identified as Alternaria spp. by the colony morphology (color and texture) and by the conidiophore and conidial characteristics. Colonies of other filamentous fungi were counted and identified to genus level on the basis of colony morphology (color and texture) and conidiophore and conidial characteristics.

Mycelia from Alternaria-like colonies of 330 isolates were transferred to APDA, and pure cultures were then obtained by transferring a single hyphal tip to fresh APDA. Isolates were kept on APDA at $5^{\circ} \mathrm{C}$ until used.

Molecular characterization. In total, 33 Alternaria isolates from moldy core and eight isolates from leaf spot of apple (Elfar et al. 2018), representing each of six morphological groups differentiated on the basis of colony morphology and characteristics of their conidiophores and conidia, were selected for molecular studies (Table 1). Fourteen of these isolates were initially examined molecularly by the ITS and HIS3 sequence analysis. However, these analyses were not very informative. Therefore, the 41 isolates were examined for Alt al, ATPase, and CAL.

DNA was extracted from the isolates from 7- to 10-day-old mycelia cultured on APDA incubated at 20 to $22^{\circ} \mathrm{C}$. Mycelia were carefully separated from the agar medium with the aid of a sterile scalpel and ground in liquid nitrogen in a porcelain mortar. Genomic DNA was extracted using a DNA extraction kit (Wizard Genomic DNA Purification Kit; Promega Corp., Madison, WI). The DNA yield was estimated by gel electrophoresis and GelRed (Biotium Inc., Alameda, CA) staining and visualized by UV transillumination at $320 \mathrm{~nm}$.

The ITS, Alt al, ATPase, CAL, and HIS3 genes were amplified using primer pairs ITS5/ITS4 (White et al. 1990), ATPDF1/ATPDR1, CALDF1/CALDR1 (Lawrence et al. 2013), Alt-for/Alt-rev (Hong et al. 2005), and H3-1a/H3-1b (Glass and Donaldson 1995), respectively. Polymerase chain reaction (PCR) was conducted in a thermal cycler (Veriti 96-Well; Applied Biosystems, Foster City, CA) in a final volume of $25 \mu \mathrm{l}$ containing $5 \mu \mathrm{l}$ of $10 \times$ PCR buffer, $1 \mu \mathrm{l}$ of $25 \mathrm{mM} \mathrm{MgCl} 2,0.2 \mu \mathrm{l}$ of $10 \mathrm{mM}$ dNTP, $1 \mu \mathrm{l}$ of a $15-\mathrm{mM}$ solution of each primer, $0.13 \mu \mathrm{l}$ containing $5 \mathrm{U}$ of Taq DNA polymerase (GoTaq Flexi DNA Polymerase, Promega Corp.), and $2 \mu \mathrm{l}$ of template DNA. The amplification protocol included preheating for $3 \mathrm{~min}$ at $95^{\circ} \mathrm{C}$; followed by 35 cycles of denaturation at $95^{\circ} \mathrm{C}$ for $30 \mathrm{~s}$, annealing for $30 \mathrm{~s}$ at $59^{\circ} \mathrm{C}$ for the ITS, $60^{\circ} \mathrm{C}$ for ATPase, $57^{\circ} \mathrm{C}$ for $C A L, 58^{\circ} \mathrm{C}$ for Alt al, and $64.5^{\circ} \mathrm{C}$ for $H I S 3$, and extension at $72^{\circ} \mathrm{C}$ for $90 \mathrm{~s}$; with a final extension for $7 \mathrm{~min}$ at $72^{\circ} \mathrm{C}$.

The PCR products were separated on $2 \%$ agarose gels in $1.0 \times$ Trisacetate-EDTA buffer and stained with GelRed, and the DNA fragments were visualized by UV transillumination at $320 \mathrm{~nm}$.

The PCR-amplified products were purified and sequenced from both directions by Macrogen Inc. (Seoul, South Korea). The sequences were edited using Proseq v.2.91 (Filatov 2002) and aligned using ClustalX v.2.1 (Larkin et al. 2007). A BLASTn search analysis was performed against reference sequences in the GenBank (https:// www.ncbi.nlm.nih.gov/) database.

A phylogenic analysis was performed for a maximum parsimony (MP) analysis with the aid of MEGA v.7.0 (Kumar et al. 2016). Gaps were treated as missing data. The MP tree was obtained using the tree-bisection-reconnection branch-swapping algorithm and 1,000 random sequence additions. Branch stability was estimated with a bootstrap analysis with 1,000 replicates. The alignment included sequences from the 33 Alternaria isolates obtained from moldy core of apple and eight Alternaria isolates obtained from leaf spot of apple in Chile (Table 1). Based on the BLASTn results, Alternaria sequences deposited in GenBank mainly more Alternaria spp. included in sections; Alternaria, Infectoriae, and Pseudoalternaria, including extypes, were used in phylogenetic analysis. Sequences of Stemphylium botryosum, S. callistephi, and S. vesicarium were included as the outgroup (Table 2). The phylogenetic analysis was performed independently for each gene. The congruence of the evolution between the ATPase and CAL genes and between ATPase, CAL, and Alt al was studied using the partition homogeneity tests with the aid of PAUP, v.4.0b10 (Swofford 2002).

Morphological characterization. Colony morphology of 19 Alternaria isolates from apple was characterized in 9-cm-diameter plastic Petri dishes containing APDA, potato carrot agar (PCA; containing $20 \mathrm{~g}$ of potato, $20 \mathrm{~g}$ of carrot, and $20 \mathrm{~g}$ of agar per liter of distilled water) (Simmons 2007), and dichloran rose Bengal yeast extract sucrose agar (DRYES; containing $2 \mathrm{mg}$ of dichloran, $25 \mathrm{mg}$ of rose Bengal, $20 \mathrm{~g}$ of yeast extract, and $150 \mathrm{~g}$ of sucrose per liter of distilled water) (Frisvad 1983). APDA and PCA plates were incubated for 7 days at $22^{\circ} \mathrm{C}$ with photoperiods of $8 \mathrm{~h}$ of light and $16 \mathrm{~h}$

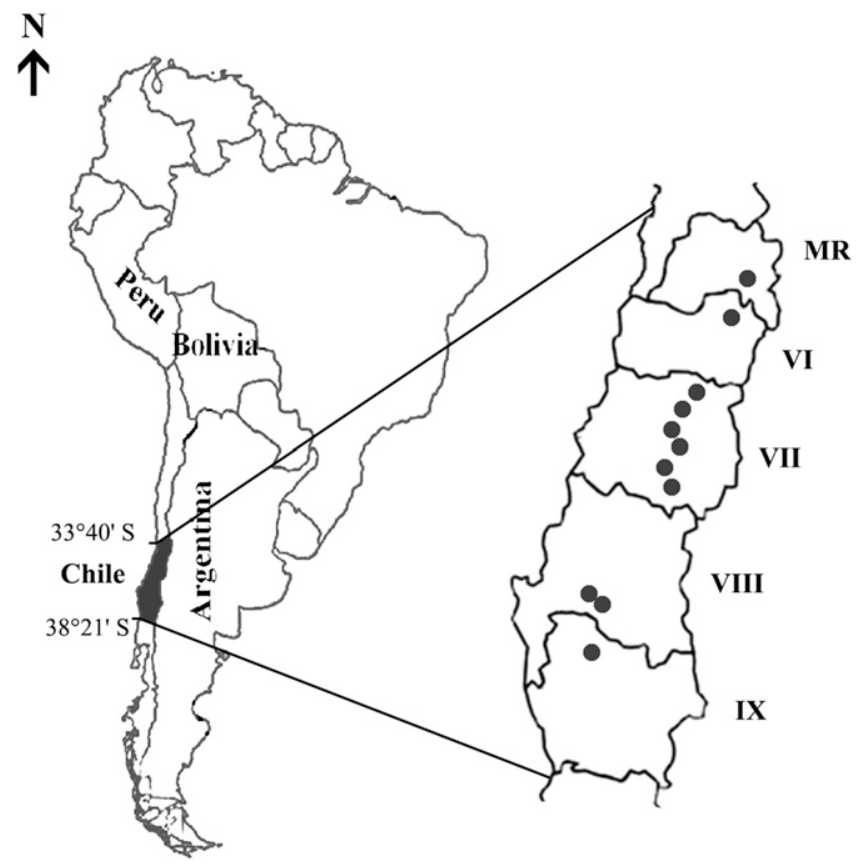

Fig. 1. Map of Chile showing the geographic distribution of apple orchards. Administrative Regions of Chile: MR = Metropolitan Region and regions VI, VII, VIII, and IX. 
of darkness. Light was provided by daylight candles (TL-D 36W/54765; Philips, Amsterdam, Netherlands) placed $40 \mathrm{~cm}$ above the plates. The DRYES plates were incubated for 7 days at $22^{\circ} \mathrm{C}$ under either daylight or darkness conditions. The color, texture, and margins of the colonies and the development of pigments on APDA were determined. The color of the colonies on DRYES was determined. The color was established with the aid of the Pantone color chart (www.pantone-colours.com). Conidia and conidiophores from three PCA plates per isolate were mounted on colorless adhesive tape and placed on top of a drop of Shear's mounting medium ( $10 \mathrm{~g}$ of potassium acetate, $200 \mathrm{ml}$ of glycerin, $300 \mathrm{ml}$ of $95 \%$ etha$\mathrm{nol}$, and $500 \mathrm{ml}$ of distilled water) before being observed under a light microscope. Conidiophore $(n=15$ per isolate) length and width, cell numbers, and branching were determined. Conidial $(n=50)$ shape, length, width, number of transepta, and beak length were measured and compared with published descriptions (Gannibal and Lawrence 2016; Poursafar et al. 2018; Pryor and Michailides 2002; Simmons 2007).

Vegetative compatibility tests. The vegetative compatibility within A. alternata ( $n=3$ isolates), $A$. arborescens ( $n=3$ isolates), A. dumosa ( $n=1$ isolate), A. frumenti ( $n=2$ isolates), A. kordkuyana ( $n=1$ isolate), and $A$. tenuissima ( $n=3$ isolates) were conducted based on the work of van der Waals et al. (2004). Two isolates were paired on APDA on $90-\mathrm{mm}$ Petri dishes. Two mycelial plugs ( $<4 \mathrm{~mm}$ in diameter) were cut from actively growing APDA cultures and placed $2 \mathrm{~cm}$ apart. Reactions were scored after 7 days of incubation in the dark at $20^{\circ} \mathrm{C}$. All isolates were paired with themselves to ensure selfcompatibility. Pairings were repeated to confirm the results. Pairings were examined macroscopically for the presence of an antagonism zone in the region of mycelial contact (van der Waals et al. 2004).

Effect of temperature on mycelial growth. The effect of temperature on the mycelial growth of A. alternata ( $n=5$ isolates), A. arborescens ( $n=5$ isolates), A. dumosa ( $n=1$ isolate), A. frumenti ( $n=2$ isolates), A. kordkuyana ( $n=1$ isolate), and A. tenuissima ( $n=5$ isolates) was studied. For this purpose, a 4-mm-diameter mycelial plug was placed in the center of each Petri dish $(9 \mathrm{~cm})$ containing $15 \mathrm{ml}$ of APDA and incubated in thermal chambers (Velp Scientifica, Milan, Italy) adjusted to 0 to $40^{\circ} \mathrm{C}\left( \pm 1^{\circ} \mathrm{C}\right)$ at $5^{\circ} \mathrm{C}$ intervals. Temperatures were checked with a HOBO PRO temperature sensor (Onset Computer Corp., Bourne, MA) with two terminals; one was outside the Petri dish and the second was placed inside the Petri dish on the agar medium surface. Petri dishes were incubated for at least $12 \mathrm{~h}$ at the desired temperature before use. The growth of two perpendicular mycelial radials was determined after 2,4 , and 6 days of incubation. Isolates showing no growth after 6 days at 0 or $40^{\circ} \mathrm{C}$ were reincubated at $22^{\circ} \mathrm{C}$ for 5 days to determine their viability. This experiment was conducted twice.

Pathogenicity tests. To stimulate sporulation, isolates were cultivated in 0.05× PDA (Pryor and Michailides 2002) for 7 days at $22^{\circ} \mathrm{C}$ with cycles of $10 \mathrm{~h}$ of light and $14 \mathrm{~h}$ of darkness. Inoculum suspensions were prepared with 10- to 14-day-old cultures on $0.05 \times$ PDA. Dishes were flooded with approximately $20 \mathrm{ml}$ of $0.05 \%$ of Tween 80
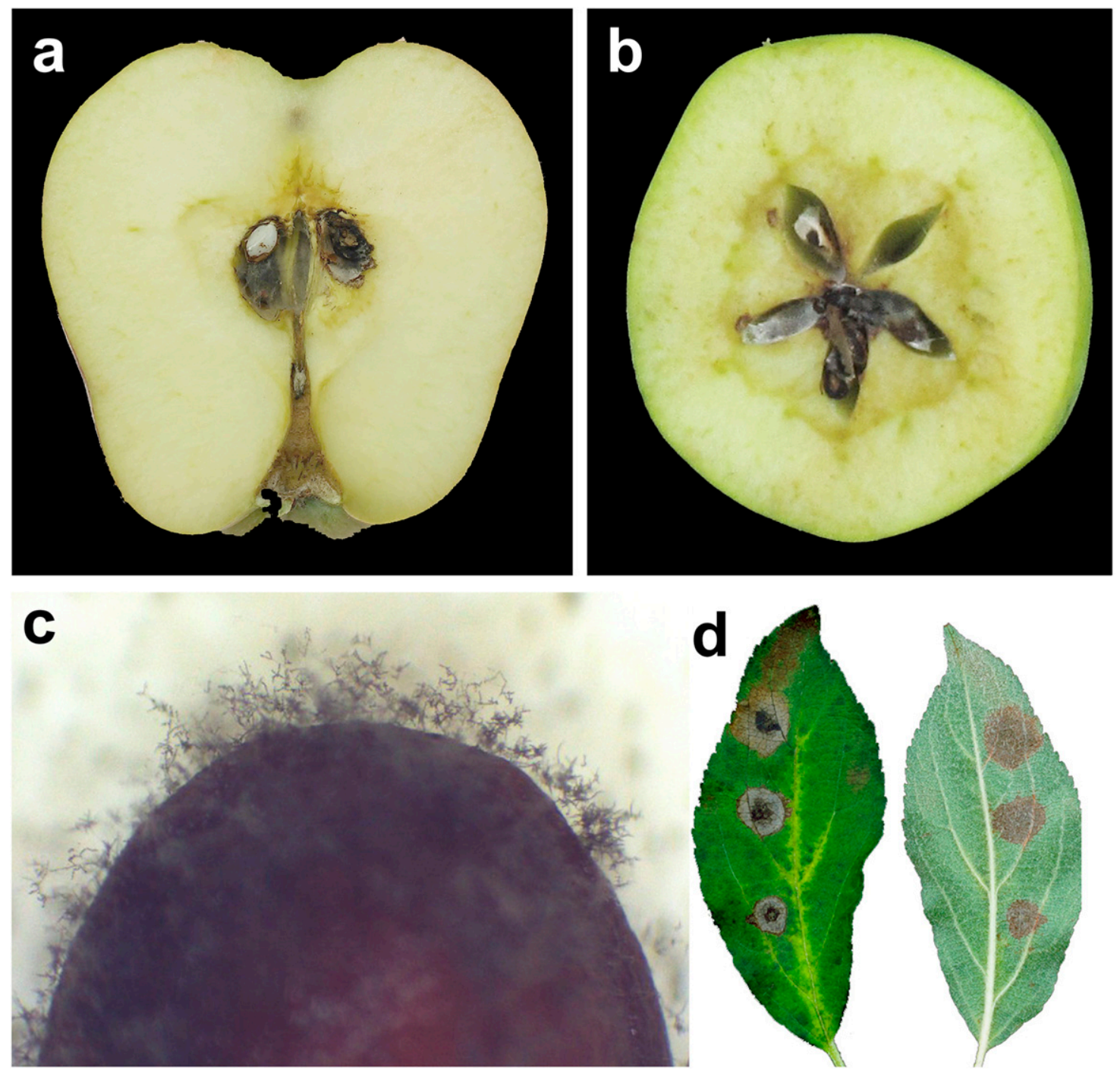

Fig. 2. Symptoms and pathogenicity of moldy core of Red Chief apple caused by Alternaria tenuissima. $\mathbf{a}$, naturally infected fruit; $\mathbf{b}$, artificially inoculated immature fruit; $\mathbf{c}$, colonization and sporulation of $A$. tenuissima on the apple seed surface; and $\mathbf{d}$, necrotic lesions on apple leaves inoculated with conidia of $A$. tenuissima. 
and the surface of the medium was scraped with a sterile scalpel. The conidial suspension was filtered through two layers gauze and the final concentration was adjusted to $1 \times 10^{6}$ conidia/ml using a hemacytometer. Isolates of $A$. alternata ( $n=5$ isolates), A. arborescens $(n=$ 5 isolates), A. dumosa ( $n=1$ isolate), A. frumenti ( $n=2$ isolates), A. kordkuyana ( $n=1$ isolate), and A. tenuissima ( $n=5$ isolates) were evaluated for pathogenicity.

Apple fruit. Immature fruit (mean equatorial diameter of $31.6 \mathrm{~mm}$ ) of Red Chief apple $(n=4)$ were surface disinfected in $75 \%$ ethanol for $5 \mathrm{~min}$ and air dried before sectioning transversally. One half of each fruit were inoculated with $10 \mu \mathrm{l}$ of conidial suspensions that were placed in each of the five carpels and then covered with the other half of the fruit to avoid rapid dehydration. Fruit were incubated at $20^{\circ} \mathrm{C}$ in a humid chamber for 10 days prior to determination of the proportion of carpels with visible mycelial growth. An equal number of fruit treated with sterile water served as the controls. Reisolations from carpels were performed on APDA. This experiment was repeated as described above using mature fruit (mean total soluble solids $13.1 \%$ ), except that the fruit were inoculated with $30 \mu \mathrm{l}$ of conidial suspensions placed in each of the five carpels.

Immature fruit and mature fruit of Red Chief apple $(n=4)$ were surface disinfected in $75 \%$ ethanol for 5 min and air dried. Each fruit was inoculated with $10 \mu \mathrm{l}$ of conidial suspension that was deposited on top of four punctures made with the aid of a sterile hypodermic needle. Fruit were incubated in humid chambers at $20^{\circ} \mathrm{C}$ for 10 days prior to determining the necrotic lesions. An equal number of fruit,

Table 1. Source of isolates of Alternaria spp. from apple obtained in commercial orchard in Central Chile and GenBank accession numbers for sequences of three genes (Alternaria major allergen Alt a1, plasma membrane ATPase, and Calmodulin) of Alternaria isolates studied

\begin{tabular}{|c|c|c|c|c|c|c|c|}
\hline \multirow[b]{2}{*}{ Species } & \multirow[b]{2}{*}{ Symptom } & \multirow[b]{2}{*}{ Locality $^{x}$} & \multirow[b]{2}{*}{ Latitude $^{y}$} & \multirow[b]{2}{*}{ Apple cultivar } & \multicolumn{3}{|c|}{ GenBank accession number ${ }^{w}$} \\
\hline & & & & & Alt a1 & ATPase & $C A L$ \\
\hline \multicolumn{8}{|c|}{ Alternaria alternata } \\
\hline $7 \mathrm{MC}^{\mathrm{z}}$ & Brown core & Río Claro, VII & $35^{\circ} 15^{\prime}$ & Red Chief & MG925174 & MG740627 & MG925132 \\
\hline $10 \mathrm{LS}$ & Leaf spot & Pirque, MR & $33^{\circ} 40^{\prime}$ & Scarlet & MG925165 & MG740618 & MG925123 \\
\hline $12 \mathrm{LS}^{\mathrm{z}}$ & Leaf spot & Morza, VII & $34^{\circ} 50^{\prime}$ & Scarlet & MG925166 & MG740619 & MG925124 \\
\hline $16 \mathrm{MC}^{\mathrm{z}}$ & Moldy core & Pirque, MR & $33^{\circ} 40^{\prime}$ & Scarlet & MG925175 & MG740628 & MG925133 \\
\hline $17 \mathrm{MC}$ & Moldy core & Graneros, VI & $34^{\circ} 4^{\prime}$ & Oregon Spur & MG925176 & MG740629 & MG925134 \\
\hline $30 \mathrm{MC}^{\mathrm{z}}$ & Moldy core & Graneros, VI & $34^{\circ} 4^{\prime}$ & Oregon Spur & MG925177 & MG740630 & MG925135 \\
\hline $36 \mathrm{MC}^{\mathrm{z}}$ & Moldy core & Los Niches, VII & $35^{\circ} 3^{\prime}$ & Scarlet & MG925178 & MG740631 & MG925136 \\
\hline \multicolumn{8}{|c|}{ A. arborescens } \\
\hline $8 \mathrm{MC}^{\mathrm{z}}$ & Brown core & Colbún, VII & $35^{\circ} 43^{\prime}$ & Red Chief & MG925179 & MG740632 & MG925137 \\
\hline $13 \mathrm{LS}^{\mathrm{z}}$ & Leaf spot & Los Ángeles, VIII & $37^{\circ} 33^{\prime}$ & Scarlet & MG925167 & MG740621 & MG925126 \\
\hline $14 \mathrm{LS}$ & Leaf spot & Los Ángeles, VIII & $37^{\circ} 33^{\prime}$ & Scarlet & MG925168 & MG740620 & MG925125 \\
\hline $19 \mathrm{MC}^{\mathrm{z}}$ & Moldy core & Pirque, MR & $33^{\circ} 40^{\prime}$ & Scarlet & MG925180 & MG740633 & MG925138 \\
\hline $23 \mathrm{MC}$ & Moldy core & Longaví, VII & $36^{\circ} 12^{\prime}$ & Scarlet & MG925181 & MG740637 & MG925142 \\
\hline $31 \mathrm{MC}$ & Moldy core & Los Ángeles, VIII & $37^{\circ} 33^{\prime}$ & Scarlet & MG925182 & MG740634 & MG925139 \\
\hline $35 \mathrm{MC}$ & Moldy core & Río Claro, VII & $35^{\circ} 15^{\prime}$ & Red Chief & MG925183 & MG740636 & MG925141 \\
\hline $38 \mathrm{MC}^{\mathrm{z}}$ & Moldy core & Traiguén, IX & $38^{\circ} 21^{\prime}$ & Fuji & MG925184 & MG740638 & MG925143 \\
\hline $39 \mathrm{MC}$ & Moldy core & Morza, VII & $34^{\circ} 50^{\prime}$ & Red Chief & MG925185 & MG740639 & MG925144 \\
\hline $40 \mathrm{MC}^{\mathrm{z}}$ & Moldy core & Graneros, VI & $34^{\circ} 4^{\prime}$ & Oregon Spur & MG925186 & MG740635 & MG925140 \\
\hline \multicolumn{8}{|l|}{ A. dumosa } \\
\hline $28 \mathrm{MC}^{\mathrm{z}}$ & Moldy core & Morza, VII & $34^{\circ} 50^{\prime}$ & Red Chief & MG925187 & MG740640 & MG925145 \\
\hline \multicolumn{8}{|c|}{ A. frumenti } \\
\hline $2 \mathrm{MC}^{\mathrm{z}}$ & Brown core & Colbún, VII & $35^{\circ} 43^{\prime}$ & Red Chief & MG925188 & MG740641 & MG925146 \\
\hline $37 \mathrm{MC}^{\mathrm{z}}$ & Moldy core & Traiguén, IX & $38^{\circ} 21^{\prime}$ & Red Chief & MG925189 & MG740642 & MG925147 \\
\hline \multicolumn{8}{|c|}{ A. kordkuyana } \\
\hline $34 \mathrm{MC}^{\mathrm{z}}$ & Moldy core & Longaví, VII & $36^{\circ} 12^{\prime}$ & Scarlet & MG925190 & MG740643 & MG925148 \\
\hline \multicolumn{8}{|c|}{ A. tenuissima } \\
\hline $1 \mathrm{MC}$ & Brown core & Río Claro, VII & $35^{\circ} 15^{\prime}$ & Red Chief & MG925191 & MG740644 & MG925149 \\
\hline $3 \mathrm{MC}$ & Dry rot & Graneros, VI & $34^{\circ} 4^{\prime}$ & Oregon Spur & MG925192 & MG740645 & MG925150 \\
\hline $4 \mathrm{LS}$ & Leaf spot & Morza, VII & $34^{\circ} 50^{\prime}$ & Scarlet & MG925170 & MG740623 & MG925128 \\
\hline $5 \mathrm{LS}$ & Leaf spot & Pirque, MR & $33^{\circ} 40^{\prime}$ & Scarlet & MG925171 & MG740625 & MG925129 \\
\hline $6 \mathrm{LS}$ & Leaf spot & Colbún, VII & $35^{\circ} 43^{\prime}$ & Red Chief & MG925172 & MG740624 & MG925130 \\
\hline $11 \mathrm{LS}^{\mathrm{z}}$ & Leaf spot & Morza, VII & $34^{\circ} 50^{\prime}$ & Scarlet & MG925173 & MG740626 & MG925131 \\
\hline $15 \mathrm{MC}^{\mathrm{z}}$ & Brown core & Río Claro, VII & $35^{\circ} 15^{\prime}$ & Red Chief & MG925193 & MG740646 & MG925151 \\
\hline $18 \mathrm{MC}^{\mathrm{z}}$ & Moldy core & Longaví, VII & $36^{\circ} 12^{\prime}$ & Scarlet & MG925194 & MG740647 & MG925152 \\
\hline $20 \mathrm{MC}$ & Moldy core & Longaví, VII & $36^{\circ} 0^{\prime}$ & Scarlet & MG925195 & MG740648 & MG925153 \\
\hline $21 \mathrm{MC}$ & Moldy core & Morza, VII & $34^{\circ} 50^{\prime}$ & Scarlet & MG925196 & MG740649 & MG925154 \\
\hline $22 \mathrm{MC}$ & Moldy core & Río Claro, VII & $35^{\circ} 15^{\prime}$ & Red Chief & MG925197 & MG740650 & MG925155 \\
\hline $24 \mathrm{MC}$ & Moldy core & Los Niches, VII & $35^{\circ} 3^{\prime}$ & Red Chief & MG925198 & MG740651 & MG925156 \\
\hline $25 \mathrm{MC}$ & Moldy core & Río Claro, VII & $35^{\circ} 15^{\prime}$ & Red Chief & MG925199 & MG740652 & MG925157 \\
\hline $26 \mathrm{MC}$ & Moldy core & Longaví, VII & $36^{\circ} 12^{\prime}$ & Red Chief & MG925200 & MG740653 & MG925158 \\
\hline $27 \mathrm{MC}$ & Moldy core & Longaví, VII & $36^{\circ} 12^{\prime}$ & Red Chief & MG925201 & MG740654 & MG925159 \\
\hline $29 \mathrm{MC}$ & Moldy core & Longaví, VII & $36^{\circ} 12^{\prime}$ & Scarlet & MG925202 & MG740655 & MG925160 \\
\hline $32 \mathrm{MC}$ & Moldy core & Río Claro, VII & $35^{\circ} 15^{\prime}$ & Red Chief & MG925203 & MG740656 & MG925161 \\
\hline $33 \mathrm{MC}^{\mathrm{z}}$ & Moldy core & Los Ángeles, VIII & $37^{\circ} 33^{\prime}$ & Scarlet & MG925204 & MG740657 & MG925162 \\
\hline $41 \mathrm{MC}$ & Moldy core & Graneros, VI & $34^{\circ} 4^{\prime}$ & Oregon Spur & MG925205 & MG740658 & MG925163 \\
\hline $42 \mathrm{MC}^{\mathrm{z}}$ & Moldy core & Graneros, VI & $34^{\circ} 4^{\prime}$ & Oregon Spur & MG925206 & MG740659 & MG925164 \\
\hline
\end{tabular}

${ }^{\mathrm{w}}$ Genes: Alt al = Alternaria major allergen Alt a1, ATPase = plasma membrane ATPase, and $C A L=$ calmodulin.

x Administrative Regions of Chile: MR = Metropolitan Region and regions VI, VII, VIII, and IX.

y Southern latitude.

${ }^{\mathrm{z}}$ Isolates used for morphological characterization, effect of temperature on mycelial growth test, and pathogenicity tests. 
injured but not inoculated, treated with sterile solution were left as the negative control.

Apple seed. Seed from immature and mature Red Chief apple were surface disinfected with $75 \%$ ethanol for $30 \mathrm{~s}$. Five seeds were aseptically placed in humid chambers $(n=4)$, inoculated with $10 \mu \mathrm{l}$ of conidial suspension per seed, and incubated at $20^{\circ} \mathrm{C}$ for 7 days before examining each seed for the presence of mycelial growth, sporulation, and necrotic lesions. An equal number of seed treated with

Table 2. Accession numbers for reference sequences of three genes of Alternaria isolates in GenBank used for phylogenetic analysis in this study

\begin{tabular}{|c|c|c|c|c|}
\hline \multirow[b]{2}{*}{ Species } & \multirow[b]{2}{*}{ Isolates $^{\mathbf{y}}$} & \multicolumn{3}{|c|}{ GenBank accession number ${ }^{x}$} \\
\hline & & Alt a1 & ATPase & $C A L$ \\
\hline Alternaria alternata & EGS $34-016^{z}$ & KP275691 & JQ671874 & JQ646208 \\
\hline A. alternata & X1191 & KJ920991 & KJ908234 & KJ920956 \\
\hline A. alternata & $\mathrm{X} 1048$ & KJ920997 & KJ908230 & KJ920957 \\
\hline A. alternata & BMP0463 & na & JQ811981 & na \\
\hline A. angustiovoidea & EGS $36-172^{z}$ & JQ646398 & JQ671869 & JQ646203 \\
\hline A. arborescens & EGS $39-128^{z}$ & AY563303 & JQ671880 & JQ646214 \\
\hline A. arborescens & BMP0462 & na & JQ811990 & na \\
\hline A. arborescens & $3 . J 24$ & KJ921023 & KJ908244 & KJ920979 \\
\hline A. arborescens & X1013 & KJ920987 & KJ908247 & KJ920949 \\
\hline A. arborescens & X1312 & KJ921008 & KJ908242 & KJ920948 \\
\hline A. argyroxiphii & EGS $35-122^{z}$ & JQ646434 & JQ671926 & JQ646260 \\
\hline A. arrhenatheri & $56492-12 \mathrm{FD}^{\mathrm{z}}$ & na & JQ693603 & na \\
\hline A. californica & EGS $52-082^{z}$ & JQ646373 & JQ671813 & JQ646147 \\
\hline A. cerialis & EGS $43-072^{z}$ & JQ646405 & JQ671883 & JQ646217 \\
\hline A. conjuncta & EGS $37-139^{z}$ & AY563281 & JQ671824 & JQ646158 \\
\hline A. daucicaulis & EGS $36-1947^{z}$ & na & JQ671822 & JQ646156 \\
\hline A. destruens & EGS 46-069z & JQ646402 & JQ671873 & JQ646207 \\
\hline A. dumosa & EGS $45-007^{z}$ & na & JQ671877 & JQ646211 \\
\hline A. ethzedia & EGS $37-143^{z}$ & AY563284 & JQ671805 & JQ646139 \\
\hline A. frumenti & EGS $44-001^{z}$ & JQ646378 & JQ671823 & JQ646157 \\
\hline A. graminicola & EGS $41-139^{z}$ & na & JQ671819 & JQ646153 \\
\hline A. herbiphorbicola & EGS 40-14 & JQ646410 & JQ671888 & JQ646222 \\
\hline A. hordeiaustralica & EGS 44-2 & na & 1811 & JQ646145 \\
\hline A. hordeicola & EGS 5 & JQ646372 & JQ671812 & JQ646146 \\
\hline A. humuli & EGS $47-140^{z}$ & na & JQ671821 & JQ646155 \\
\hline A. incomplexa & EGS $17-103^{z}$ & JQ646374 & JQ671815 & JQ646149 \\
\hline A. infectoria & EGS $27-193^{z}$ & FJ266502 & JQ671804 & JQ646138 \\
\hline A. infectoria & $3 . J 14$ & KJ921017 & KJ908219 & KJ920977 \\
\hline A. infectoria & $\mathrm{X} 1273$ & KJ920982 & KJ908218 & KJ920953 \\
\hline A. intercepta & EGS 49-137z & JQ646380 & JQ671826 & JQ646160 \\
\hline A. kordkuyana & KQ-20 $0^{z}$ & na & MF033860 & na \\
\hline A. limoniasperae & EGS $45-100^{z}$ & JQ646370 & JQ671879 & JQ646213 \\
\hline A. malorum & EGS $52.153^{z}$ & JQ646369 & JQ671800 & JQ646134 \\
\hline A. merytae & EGS 46-1 & na & JQ671820 & JQ646154 \\
\hline A. metachromatica & EGS $38-132^{z}$ & AY563285 & JQ671809 & JQ646143 \\
\hline A. novae-zelandiae & EGS $48-092^{z}$ & JQ646379 & JQ671825 & JQ646159 \\
\hline A. oregonensis & EGS 29-194z & AY563283 & JQ671827 & JQ646161 \\
\hline A. parvicaespitosa & $\mathrm{X} 1272^{\mathrm{z}}$ & KJ920981 & KJ908217 & KJ920952 \\
\hline A. rosae & EGS $41-130^{z}$ & JQ646370 & JQ671803 & JQ646137 \\
\hline A. tenuissima & EGS $34.015^{z}$ & KP275690 & JQ811989 & JQ646209 \\
\hline A. tenuissima & BMP2256 & na & JQ811983 & na \\
\hline A. tenuissima & BMP1254 & na & JQ811988 & na \\
\hline A. triticimaculans & EGS $41-050^{z}$ & na & JQ671806 & JQ646140 \\
\hline A. triticina & EGS $17-061^{z}$ & JQ646371 & JQ671808 & JQ646142 \\
\hline A. ventricosa & EGS $52-075^{z}$ & JQ646377 & JQ671818 & JQ646152 \\
\hline A. viburni & EGS 49-147z & JQ646375 & JQ671816 & JQ646150 \\
\hline $\begin{array}{l}\text { Stemphylium } \\
\text { botryosum }\end{array}$ & BMP 0360 & AY563274 & JQ671767 & JQ646101 \\
\hline S. callistephi & & & & JQ64 \\
\hline S. vesicarium & BMP 0374 & AY563275 & JQ671768 & JQ646102 \\
\hline
\end{tabular}

× Genes: Alt a1 = Alternaria major allergen Alt a1, ATPase $=$ plasma membrane ATPase, and $C A L=$ calmodulin; na $=$ sequences not available in GenBank.

y BMP = B. M. Pryor, Division of Plant Pathology, Department of Plant Sciences; EGS = E. G. Simmons, Mycological Services, Crawfordsville, IN 47933; 3.J = Pryor and Michailides 2002; and X = Zhu and Xiao 2015.

${ }^{\mathrm{z}}$ Ex-type. sterile water served as the negative controls. Reisolations from surface mycelial growth and necrotic lesions were attempted on APDA.

Apple leaves. Detached leaves of Red Chief apple $(n=4)$, taken from the newest leaves of the shoots, were surface disinfected in $1 \% \mathrm{NaOCl}$ for $1 \mathrm{~min}$ followed by sterile distilled water for $1 \mathrm{~min}$ and air dried. Then, the leaves were wounded with three punctures made with a sterile hypodermic needle in the apical, basal, and middle regions of each leaf blade. Leaves were inoculated by delivering $15 \mu$ l of conidial suspension per wound site. Leaves were incubated at $20^{\circ} \mathrm{C}$ in a humid chamber for 7 days before the diameters of the lesions were determined. An equal number of wounded leaves treated with sterile water served as the negative controls. Reisolations from the necrotic lesions on APDA were attempted, and isolates were identified on the basis of the conidial morphology. This experiment was conducted twice. This experiment was repeated as described above using unwounded leaves.

Design and statistical analysis. All experimental treatments were performed in a completely randomized design with four replicates. Means were separated according to Fisher's least significant difference test $(P<0.05)$. All analyses were performed with the aid of SigmaStat 3.1 (Systat Software Inc., San Jose, CA). Data percentages were arcsine $\sqrt{ }(x / 100)$ transformed and necrotic lesion length data were transformed to $\operatorname{Ln}(x+1)$ prior to analysis; however, nontransformed data are presented. The mean daily radial growth rates were estimated by linear regression analysis between $y=$ mycelial growth and $x=$ time.

\section{Results}

Sampling locations and fungal isolation. Of 2,200 fruit sampled, $653(29.7 \%)$ were diseased fruit, characterized by the presence of a gray to dark olive-green cottony mycelium (moldy core). In addition, $158(7.2 \%)$ fruit showed a brown core, $31(1.4 \%)$ fruit showed dry rot, and $4(0.2 \%)$ fruit showed wet rot. A moldy core was most prevalent, varying from 16 to $46 \%$ in Oregon Spur, Red Chief, and Scarlet apple and between 4 and $13 \%$ in Fuji apple. The brown core prevalence varied from 0.1 to $69 \%$. A low prevalence of core rot was determined in Oregon Spur, Red Chief, and Scarlet apple (0.3 to 3.0\%). Granny Smith apple fruit were symptomless (Table 3).

Species of Alternaria were the most frequently and consistently isolated fungi, found in $56.2 \%$ of the apple samples in 2014-15 and $79.2 \%$ in 2015-16, followed by (in order of species by frequency) Cladosporium, Penicillium, Stemphylium, Epicoccum, Botrytis, and Fusarium (Table 3). In total, 330 isolates of Alternaria spp. were obtained from moldy core apple fruit (Table 3 ).

Molecular characterization. Sequences of ATPase of the Alternaria isolates from apple ranged from 1,188 to $1,197 \mathrm{bp}$. MP analysis produced a consensus tree (Fig. 3) inferred from the two most parsimonious trees (tree length $[\mathrm{TL}]=567$, consistency index $[\mathrm{CI}]=0.747$, retention index $[\mathrm{RI}]=0.953$, and rescaled consistency index $[\mathrm{RC}]=0.713$ ). The phylogenetic tree obtained with ATPase sequences delimited six main clades (groups A to F) (Fig. 3). Clade I (group A), with 97\% bootstrap support, contained sequences of isolates of $A$. alternata from Chilean apple together with the A. alternata ex-type (JQ671874) and A. destruens ex-type (JQ671873). Clade II (group B), with 88\% bootstrap support, contained isolates of A. tenuissima, including the sequence of the A. tenuissima ex-type (JQ811989). Clade III (group F), with $70 \%$ bootstrap support, grouped isolates of $A$. dumosa together with the A. dumosa ex-type (JQ671877). Clade IV (group C), with 100\% bootstrap support, contained isolates of $A$. arborescens, including the A. arborescens ex-type (JQ671880). Clade V (group D), with 91\% bootstrap support, grouped isolates from moldy core of Chilean apple together with ATPase sequences of A. frumenti (JQ671823) in sect. Infectoriae. Clade VI (group E), with $99 \%$ bootstrap support, contained one isolate from Chilean apple that was grouped together with A. kordkuyana ex-type (MF033860) in sect. Pseudoalternaria (Fig. 3).

Sequences of $C A L$ of the Alternaria spp. from apple ranged from 775 to 794 nucleotides. MP analysis produced one parsimonious trees $(\mathrm{TL}=355, \mathrm{CI}=0.785, \mathrm{RI}=0.977$, and $\mathrm{RC}=0.768)$. The phylogenetic tree obtained with $C A L$ sequences delimited four main clades. Clade I, with $82 \%$ bootstrap support, contained isolates of the A. tenuissima, A. destruens ex-type (JQ646207), and A. limoniasperae ex-type (JQ646213). Clade II, with 79\% bootstrap support, grouped 
isolates of A. dumosa together with the A. dumosa ex-type (JQ646211). Clade III, with $99 \%$ bootstrap support, contained sequences of isolates of $A$. arborescens, including the sequences of the A. arborescens extype (AY563303), A. cerealis (JQ646217), and A. angustiovoidea (JQ646203). Clade IV, with 96\% bootstrap support, grouped isolates A. alternata and A. tenuissima together with the ex-types (JQ646208 and JQ646209). Clade V, with $97 \%$ bootstrap support, contained isolate from Chilean apple, including the A. parvicaespitosa ex-type (KJ920952) of sect. Pseudoalternaria. A DNA sequence of A. kordkuyana ex-type for the $C A L$ gene is not available. Clade VII, with $100 \%$ bootstrap support, contained sequences of isolates from Chilean apple, including the ex-type of A. infectoria, A. frumenti, and other Alternaria spp. of sect. Infertoriae.

Sequences of Alt al of the Alternaria spp. from apple ranged from 483 to 485 nucleotides. MP analysis yielded four most parsimonious trees $(\mathrm{TL}=200, \mathrm{CI}=0.700, \mathrm{RI}=0.940$, and $\mathrm{RC}=0.658$ ). The phylogenetic tree obtained with Alt al sequences delimited five main clades. Clade I, with $100 \%$ bootstrap support, contained sequences of isolates of A. alternata and A. tenuissima from Chilean apple that were grouped together with Alt al sequences of the A. alternata and A. tenuissima ex-types (KP275691 and KP275690). Clade II, with 100\% bootstrap support, contained isolates of $A$. arborescens and A. frumenti, including sequences of the $A$. arborescens ex-type (AY563303). Clade III, with $100 \%$ bootstrap support, grouped isolates A. alternata, A. dumosa, and $A$. tenuissima together with the $A$. destruens and $A$. herbiphorbicola ex-types. Clade IV, with $70 \%$ bootstrap support, contained the ex-type of A. infectoria and other Alternaria spp. of sect. Infertoriae but none of the Chilean isolates were grouped in clade IV. Clade V, with $98 \%$ bootstrap support, contained one isolate from Chilean apple, including the ex-type A. rosae and A. parvicaespitosa of sect. Pseudoalternaria. A DNA sequence of A. kordkuyana ex-type for Alt al gene is not available.

The partitioned homogeneity test showed significant differences $(P<0.05)$ between the Alt al, ATPase, and CAL genes and between ATPase and CAL. Therefore, the concatenated analysis of these genes was not performed.

The MP analysis of the rDNA ITS sequence was not informative to clearly delimit the small-spored species of Alternaria associated with moldy core of apple in the present study. Similarly, the phylogenetic analysis of the partial coding sequence of the HIS gene was not useful to distinguish isolates of Alternaria spp. from moldy core of apple.

Morphological characterization. All Alternaria isolates produced single conidiophores and catenulate muriform, brown to golden-brown conidia. However, six groups (A, B, C, D, E, and F) of isolates were differentiated based on the colony morphology and characteristics of their conidiophores and conidia. Isolates in group A were identified as A. alternata in sect. Alternaria and produced cottony, gray to green (Pantone number 5777-5763) colonies on APDA and gray-green colonies on DRYES medium. Isolates produced conidial chains with numerous secondary chains branching on short conidiophores (mean $49.8 \pm 11.5 \times 4.0 \pm 0.5 \mu \mathrm{m}$ ) of 3 to 6 cells. Conidia were ovoid to ellipsoid (mean $28.3 \pm 4.4 \times 11.7 \pm$ $1.6 \mu \mathrm{m}$ ) with 3 to 7 transepta and 0 to 1 longisepta (Fig. 4; Table 4).

Isolates in group B were identified as A. tenuissima in sect. Alternaria and produced cottony, olive brown (Pantone number 58155825) colonies with slight concentric growth rings and prominent white margins on APDA and gray-green to yellow-green colonies on DRYES medium. The isolates produced conidial chains of 4 to 12 conidia, rarely with a lateral branch, on conidiophores of $41.1 \pm 9.7 \times 4.2 \pm$ $0.5 \mu \mathrm{m}$ of 4 to 5 cells. Conidia were ovoid to obclavate with a narrow tapered upper half (mean $34.7 \pm 5.9 \times 11 \pm 1.3 \mu \mathrm{m}$ ) with 3 to 6 transepta, with the majority of the conidia exhibiting a dark transverse median septa, with 0 to 2 longisepta and a long beak (Fig. 4; Table 4).

Isolates in group $\mathrm{C}$ were identified as A. arborescens in sect. Alternaria and produced cottony, olive-brown (Pantone number 58155825) colonies with prominent concentric growth rings and narrow white margins on APDA and dark yellow-green colonies on DRYES medium. Isolates produced conidial chains of 2 to 7 conidia, with a very distinctive long conidiophores (mean $225.4 \pm 80 \times 3.8 \pm$ $0.5 \mu \mathrm{m}$ ) of 7 to 10 cells and extended secondary conidiophores. Sporulation was concentrated near the apex of secondary, tertiary, and even quaternary conidiophores. Conidia were ovoid to ellipsoid (mean $23.2 \pm 4.2 \times 10.1 \pm 1.3$ ) with 1 to 4 transepta and no longisepta or, rarely, 1 longisepta (Fig. 4; Table 4).

Isolates in group D were identified as A. frumenti in sect. Infectoriae and produced floccules, gray to yellow-green (Pantone number 5777-5783) colonies with slight concentric growth rings on APDA and white colonies on DRYES medium. Primary conidiophores were relatively short (mean $63.8 \pm 16.4 \times 4.2 \pm 0.7 \mu \mathrm{m}$ ) of 3 to 6 cells. Secondary conidiophores were branched and geniculated. Conidia were ovoid to ellipsoid (mean $33.7 \pm 6 \times 10.2 \pm 1.6 \mu \mathrm{m}$ ) with 2 to 5 transepta and 0 to 1 longisepta in 0 to 3 transverse segments, produced on secondary and tertiary conidiophores (Fig. 4; Table 4).

The isolate in group $\mathrm{E}$ was identified as A. kordkuyana in sect. Pseudoalternaria. This isolate produced gray to dark-green (Pantone number 5763-5743) colonies with slight concentric growth rings on APDA and white colonies on DRYES medium. Isolates produced short conidial chains of 1 to 6 conidia with lateral chains branching on short conidiophores (mean $56.1 \pm 10.8 \times 3.8 \pm 0.5 \mu \mathrm{m}$ ) of 4 to

Table 3. Frequency of isolation of Alternaria spp. and other filamentous fungi obtained from apple fruit $(n=2,200)$ collected and harvested in commercial orchards in Central Valley of Chile

\begin{tabular}{|c|c|c|c|c|c|c|c|c|c|c|c|c|}
\hline \multirow[b]{2}{*}{ Growing season, cultivar } & \multicolumn{4}{|c|}{ Prevalence $(\%)^{y}$} & \multicolumn{8}{|c|}{ Isolates $(\%)^{\mathrm{z}}$} \\
\hline & MC & BC & DR & $\overline{\text { WR }}$ & Alt & Bot & Cla & Epi & Fus & Pen & Ste & Others \\
\hline \multicolumn{13}{|l|}{ 2014-15 } \\
\hline \multicolumn{13}{|l|}{ Open-sinus } \\
\hline Fuji $(n=200)$ & 4.0 & 4.5 & 0.5 & 0.0 & 6.4 & 0.0 & 0.5 & 0.0 & 0.0 & 0.0 & 1.1 & 1.1 \\
\hline Oregon Spur $(n=100)$ & 16.0 & 69.0 & 3.0 & 1.0 & 23.0 & 0.0 & 7,0 & 4.8 & 0.5 & 8.0 & 0.5 & 3.7 \\
\hline Red Chief $(n=200)$ & 26.5 & 19.0 & 1.0 & 0.0 & 26.8 & 0.0 & 8.0 & 0.0 & 0.0 & 1.1 & 1.1 & 6.4 \\
\hline Total $(\%)$ & $\ldots$ & $\ldots$ & $\ldots$ & $\ldots$ & 56.2 & 0.0 & 15.5 & 4.8 & 0.5 & 9.1 & 2.7 & 11.2 \\
\hline \multicolumn{13}{|l|}{ Closed-sinus } \\
\hline Granny Smith $(n=100)$ & 0.0 & 0.0 & 0.0 & 0.0 & 0.0 & 0.0 & 0.0 & 0.0 & 0.0 & 0.0 & 0.0 & 0.0 \\
\hline \multicolumn{13}{|l|}{$2015-16$} \\
\hline \multicolumn{13}{|l|}{ Open-sinus } \\
\hline Fuji $(n=100)$ & 13.0 & 7.0 & 0.0 & 0.0 & 3.5 & 0.0 & 0.3 & 0.0 & 0.0 & 0.0 & 0.0 & 0.0 \\
\hline Oregon Spur $(n=100)$ & 46.0 & 24.0 & 2.0 & 1.0 & 16.0 & 0.3 & 2.4 & 0.0 & 0.0 & 3.1 & 3.1 & 4.9 \\
\hline Red Chief $(n=700)$ & 38.9 & 0.1 & 0.9 & 0.3 & 30.9 & 0.3 & 0.0 & 0.0 & 0.3 & 0.3 & 0.0 & 2.1 \\
\hline Scarlett $(n=600)$ & 40.8 & 1.7 & 2.8 & 0.0 & 28.8 & 0.0 & 0.3 & 0.0 & 0.0 & 0.7 & 0.7 & 1.4 \\
\hline Total $(\%)$ & $\ldots$ & $\ldots$ & $\ldots$ & $\ldots$ & 79.2 & 0.7 & 3.1 & 0.0 & 0.3 & 4.2 & 3.8 & 8.4 \\
\hline \multicolumn{13}{|l|}{ Closed-sinus } \\
\hline Granny Smith $(n=100)$ & 0.0 & 0.0 & 0.0 & 0.0 & 0.0 & 0.0 & 0.0 & 0.0 & 0.0 & 0.0 & 0.0 & 0.0 \\
\hline
\end{tabular}

${ }^{\mathrm{y}}$ Percentages based on total number of fruit per apple cultivar. $\mathrm{MC}=$ moldy core, $\mathrm{BC}=$ brown core, $\mathrm{DR}=$ dry rot, and $\mathrm{WR}=$ wet rot.

${ }^{\mathrm{z}}$ Percentages were calculated from the total fungal isolates, $n=187$ and $n=287$ obtained in 2014-15 and 2015-16 growing seasons, respectively. Alt $=$ Alternaria spp., Bot $=$ Botrytis spp., Cla $=$ Cladosporium spp., Epi $=$ Epicoccum spp., Fus $=$ Fusarium spp., Pen $=$ Penicillium spp., and Ste $=$ Stemphylium spp. 
6 cells. Conidia were ovoid to elliptical (mean $24.7 \pm 6.8 \times 9.7 \pm$ $2.2 \mu \mathrm{m}$ ) with 1 to 4 transepta and 0 to 1 longisepta (Fig. 4; Table 4).

The isolate in group F was identified as A. dumosa in sect. Alternaria. This isolate produced cottony, light brown-green (Pantone number 5803-5783) colonies with slight concentric growth rings on APDA and gray-green colonies on DRYES medium. Isolates produced conidial chains with numerous secondary chains branching on short conidiophores (mean $60.2 \pm 19.9 \times 3.9 \pm 0.4 \mu \mathrm{m}$ ) of 4 to 5 cells. Conidia were ovoid (mean $18.3 \pm 3 \times 8.9 \pm 1.6 \mu \mathrm{m}$ ) with 1 to 4 transepta and 0 to 1 longisepta (Fig. 4; Table 4).

Vegetative compatibility tests. Of 169 pairings studied, 150 pairings were consistently compatible, developing a clear nonantagonistic line at the contact zone; 1 pairing was incompatible; and 18 pairings were uncertain (Table 5).

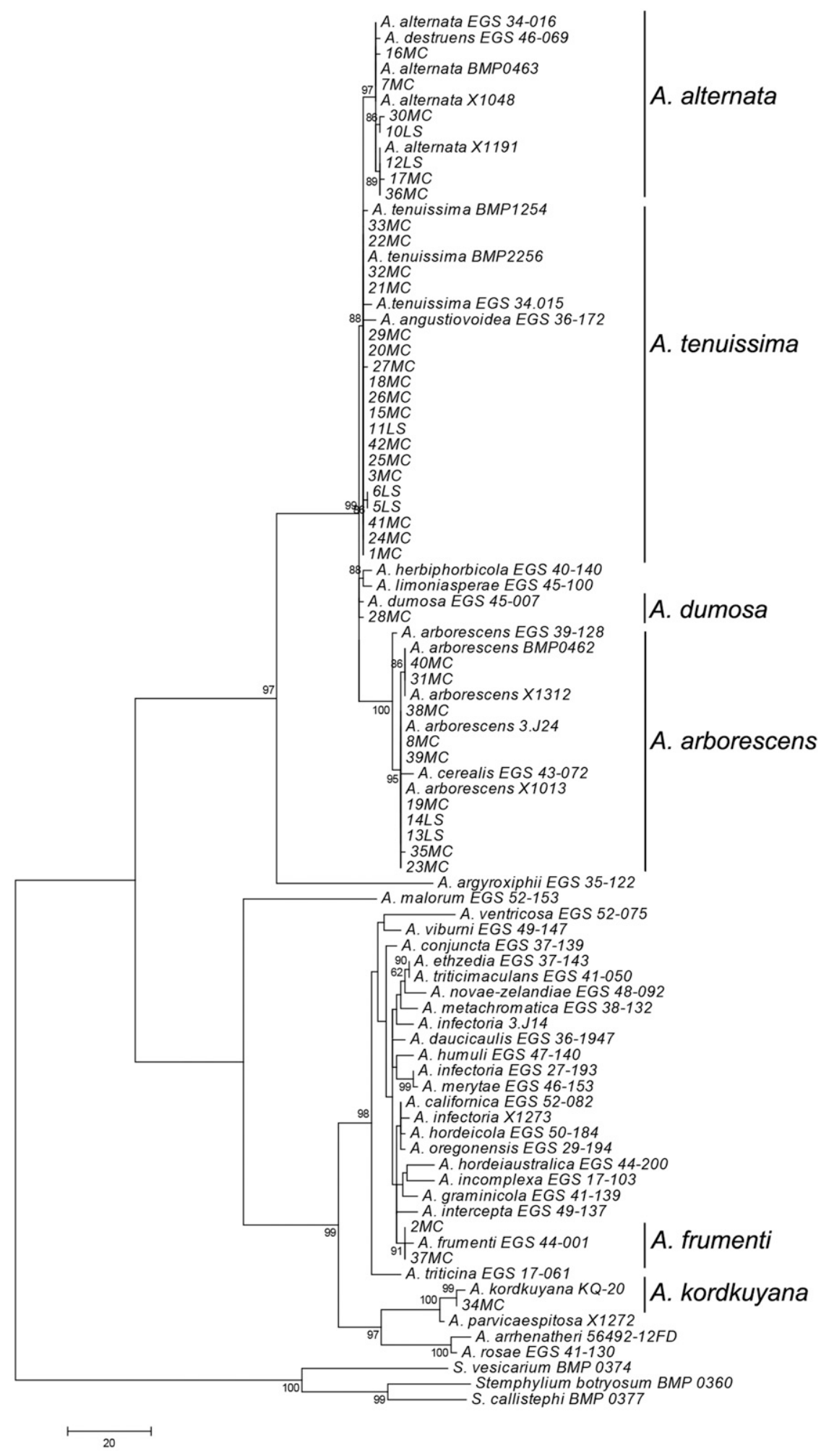

Fig. 3. Phylogenetic tree obtained from maximum-parsimony analysis of the plasma membrane ATPase gene from sequences of Alternaria spp. from Chilean apple and from sequences of ex-types in GenBank. The consensus tree inferred from the two most parsimonious trees and bootstrap values are shown. The tree was rooted with Stemphylium botryosum, $S$. callistephi, and $S$. vesicarium. Tree length $=567$, consistency index $=0.747$, retention index $=0.953$, and rescaled consistency index $=$ 0.713. Numbers and MC or LS are Alternaria isolates from apple in Chile; other codes are isolates from GenBank. 
Effect of temperature on mycelial growth. The radial mycelial growth of the Alternaria isolates was significantly $(P<0.001)$ affected by temperature and isolate, with a significant $(P<0.001)$ temperature-isolate interaction. All Alternaria isolates were able to grow between 5 and $35^{\circ} \mathrm{C}$ (Fig. 5). However, some isolates showed very slight growth $(<1 \mathrm{~mm}$ per 6 days $)$ at $0^{\circ} \mathrm{C}$. All isolates regained normal growth at $22^{\circ} \mathrm{C}$. Optimal radial mycelial growth was obtained at $25^{\circ} \mathrm{C}$. No growth occurred at $40^{\circ} \mathrm{C}$ in 8 days. Only some isolates of $A$. arborescens (isolate $38 \mathrm{MC}$ ), A. dumosa (isolate 28MC), and A. tenuissima (isolate $33 \mathrm{MC}$ ) were able to regain growth after 5 days

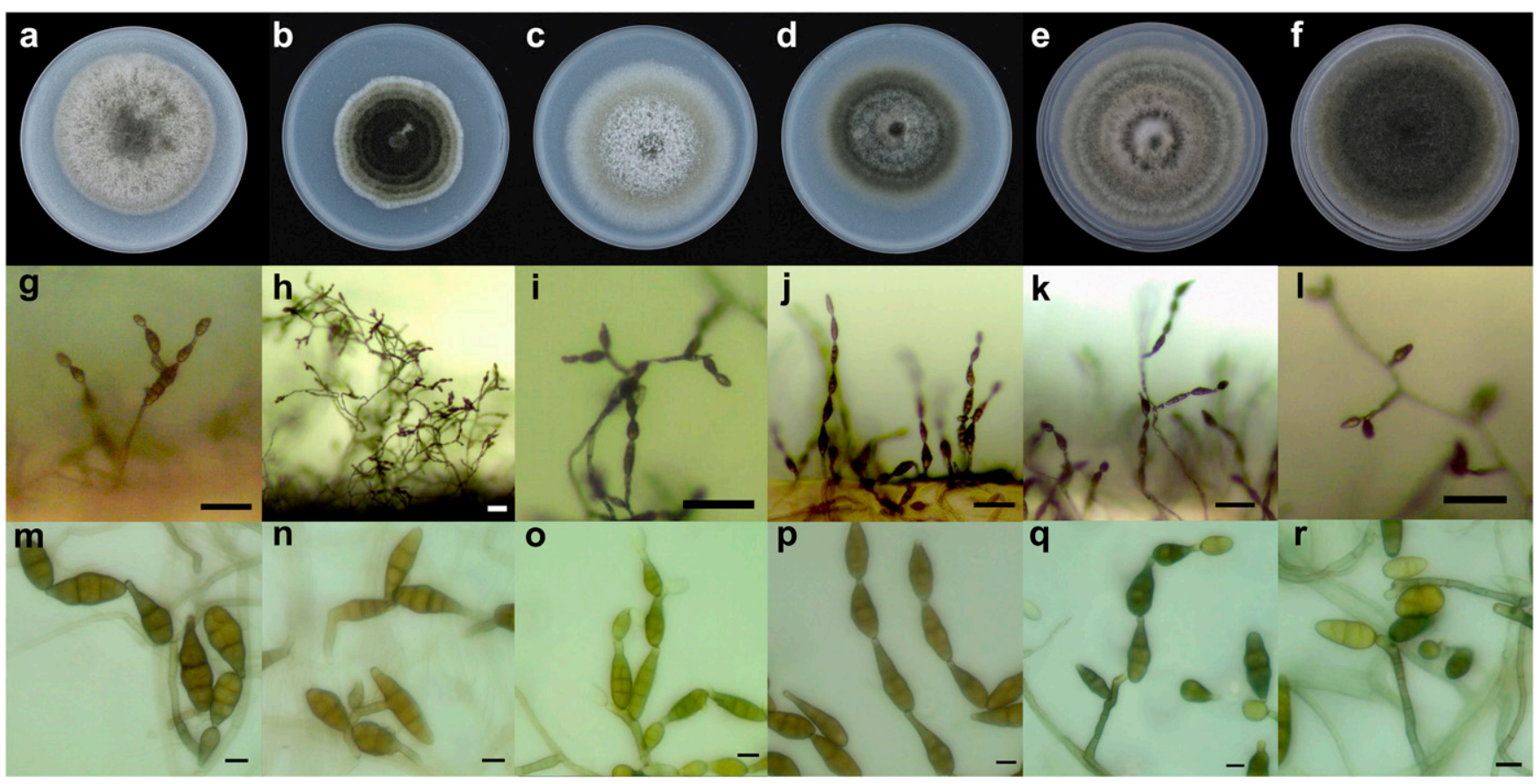

Fig. 4. Morphological characteristics of species of Alternaria isolated from apple moldy core. a to f, Colony morphology on acidified potato dextrose agar plates incubated for 7 days at $22^{\circ} \mathrm{C}$ in cycles of $8 \mathrm{~h}$ of light and $16 \mathrm{~h}$ of darkness; and $\mathbf{g}$ to $\mathbf{r}$, sporulation pattern on potato carrot agar plates incubated for 7 days at $22^{\circ} \mathrm{C}$ in cycles of $8 \mathrm{~h}$ of light and $16 \mathrm{~h}$ of darkness. $\mathbf{a}, \mathbf{g}$, and $\mathbf{m}$, Alternaria alternate; $\mathbf{b}, \mathbf{h}$, and $\mathbf{n}, A$. arborescens; $\mathbf{c}, \mathbf{i}$, and $\mathbf{o}, A$. frumenti; $\mathbf{d}, \mathbf{j}$, and $\mathbf{p}, A$. tenuissima; $\mathbf{e}, \mathbf{k}$, and $\mathbf{q}, A$. dumosa; and $\mathbf{f}, \mathrm{l}$, and $\mathbf{r}, \mathrm{A}$. kordkuyana. Scale bars: $\mathrm{g}$ to $\mathrm{I}=50 \mu \mathrm{m}$ and $\mathrm{m}$ to $\mathrm{r}=10 \mu \mathrm{m}$.

Table 4. Morphometric characterization of conidiophores and conidia of Alternaria spp. isolated from moldy core of apple fruit in Chile

\begin{tabular}{|c|c|c|c|c|c|c|}
\hline \multirow[b]{2}{*}{ Isolates (group) } & \multirow{2}{*}{$\frac{\text { Colony }^{w}}{\text { Growth }(\mathrm{mm} / \text { day })}$} & \multicolumn{2}{|c|}{ Conidiophores $^{\mathrm{x}, \mathrm{y}}$} & \multicolumn{3}{|c|}{ Conidia $^{\mathbf{y}, \mathbf{z}}$} \\
\hline & & Length $(\mu \mathrm{m})$ & Width $(\mu \mathrm{m})$ & Length $(\mu \mathrm{m})$ & Width ( $\mu \mathrm{m})$ & L/W \\
\hline \multicolumn{7}{|c|}{ Alternaria alternata (A) } \\
\hline $7 \mathrm{MC}$ & $7.3 \pm 0.3$ & $36.4 \pm 7.5$ & $4.3 \pm 0.5$ & $32.3 \pm 5.2$ & $13.1 \pm 1.7$ & $1.8 \pm 0.3$ \\
\hline 12LS & $8.5 \pm 0.4$ & $56.3 \pm 11.9$ & $3.9 \pm 0.4$ & $23.4 \pm 3.4$ & $10.0 \pm 1.3$ & $2.4 \pm 0.4$ \\
\hline $16 \mathrm{MC}$ & $8.3 \pm 0.2$ & $54.2 \pm 13.1$ & $3.9 \pm 0.5$ & $35.4 \pm 6.1$ & $13.3 \pm 2.1$ & $2.7 \pm 0.5$ \\
\hline $30 \mathrm{MC}$ & $9.0 \pm 0.1$ & $57.9 \pm 14.9$ & $4.2 \pm 0.5$ & $26.2 \pm 4.2$ & $11.6 \pm 1.6$ & $2.3 \pm 0.4$ \\
\hline $36 \mathrm{MC}$ & $7.5 \pm 0.2$ & $44.3 \pm 10.3$ & $3.9 \pm 0.4$ & $24.3 \pm 3.2$ & $10.7 \pm 1.2$ & $2.3 \pm 0.3$ \\
\hline \multicolumn{7}{|l|}{ A. arborescens $(\mathrm{C})$} \\
\hline $8 \mathrm{MC}$ & $6.3 \pm 0.3$ & $239.0 \pm 104.3$ & $4.1 \pm 0.5$ & $29.1 \pm 5.8$ & $10.6 \pm 1.6$ & $2.8 \pm 0.6$ \\
\hline $13 \mathrm{LS}$ & $6.7 \pm 0.3$ & $226.7 \pm 94.5$ & $3.5 \pm 0.5$ & $21.6 \pm 3.3$ & $9.2 \pm 1.1$ & $2.4 \pm 0.4$ \\
\hline $19 \mathrm{MC}$ & $8.1 \pm 0.2$ & $208.9 \pm 73.6$ & $3.8 \pm 0.6$ & $22.2 \pm 3.6$ & $11.1 \pm 1.2$ & $2.1 \pm 0.3$ \\
\hline $38 \mathrm{MC}$ & $7.6 \pm 0.3$ & $236.5 \pm 62.9$ & $3.5 \pm 0.5$ & $19.9 \pm 4.1$ & $9.3 \pm 1.2$ & $2.2 \pm 0.5$ \\
\hline $40 \mathrm{MC}$ & $7.3 \pm 0.3$ & $216.1 \pm 64.6$ & $4.0 \pm 0.3$ & $23.4 \pm 4.2$ & $10.4 \pm 1.6$ & $2.3 \pm 0.4$ \\
\hline \multicolumn{7}{|l|}{ A. dumosa $(\mathrm{F})$} \\
\hline $28 \mathrm{MC}$ & $9.8 \pm 0.2$ & $60.2 \pm 13.9$ & $3.9 \pm 0.4$ & $18.3 \pm 3.0$ & $8.9 \pm 1.6$ & $2.1 \pm 0.4$ \\
\hline \multicolumn{7}{|l|}{ A. frumenti (D) } \\
\hline $2 \mathrm{MC}$ & $9.0 \pm 0.3$ & $56.6 \pm 18.6$ & $4.5 \pm 0.8$ & $28.8 \pm 4.8$ & $9.3 \pm 1.0$ & $2.2 \pm 0.6$ \\
\hline $37 \mathrm{MC}$ & $8.9 \pm 0.1$ & $70.9 \pm 14.1$ & $3.9 \pm 0.6$ & $38.6 \pm 7.1$ & $11.0 \pm 2.1$ & $3.6 \pm 0.9$ \\
\hline \multicolumn{7}{|l|}{ A. kordkuyana (E) } \\
\hline $34 \mathrm{MC}$ & $12.0 \pm 0.2$ & $56.1 \pm 10.8$ & $3.8 \pm 0.5$ & $24.7 \pm 6.8$ & $9.7 \pm 2.2$ & $2.6 \pm 0.5$ \\
\hline \multicolumn{7}{|l|}{ A. tenuissima (B) } \\
\hline $11 \mathrm{LS}$ & $7.9 \pm 0.3$ & $43.1 \pm 7.4$ & $4.3 \pm 0.4$ & $31.0 \pm 5.3$ & $11.9 \pm 1.6$ & $2.6 \pm 0.5$ \\
\hline $15 \mathrm{MC}$ & $6.0 \pm 0.3$ & $39.3 \pm 7.9$ & $3.9 \pm 0.5$ & $35.6 \pm 5.7$ & $10.7 \pm 1.3$ & $2.4 \pm 0.5$ \\
\hline $18 \mathrm{MC}$ & $6.6 \pm 0.2$ & $41.6 \pm 11.2$ & $4.3 \pm 0.5$ & $36.5 \pm 5.9$ & $11.5 \pm 1.4$ & $3.2 \pm 0.7$ \\
\hline $33 \mathrm{MC}$ & $8.2 \pm 0.2$ & $49.1 \pm 10.9$ & $4.4 \pm 0.7$ & $31.2 \pm 6.7$ & $9.1 \pm 1.0$ & $2.3 \pm 0.6$ \\
\hline $42 \mathrm{MC}$ & $8.6 \pm 0.3$ & $32.2 \pm 11.1$ & $4.0 \pm 0.5$ & $39.0 \pm 6.1$ & $11.8 \pm 1.1$ & $3.3 \pm 0.6$ \\
\hline
\end{tabular}

${ }^{\mathrm{w}}$ Growth rate: means of four plates \pm standard error. Incubated on acidified potato dextrose agar for 6 days at $25^{\circ} \mathrm{C}$ in the dark.

$\mathrm{x}$ Means of at least 15 primary conidiophores per isolates \pm standard deviation.

y Incubated on potato carrot agar for 7 days at $22^{\circ} \mathrm{C}$ in cycles of $8 \mathrm{~h}$ of light and $16 \mathrm{~h}$ of darkness.

${ }^{\mathrm{z}}$ Means of at least 50 conidia per isolate \pm standard deviation. $\mathrm{L} / \mathrm{W}=$ length/width ratio. 
at $22^{\circ} \mathrm{C}$. The differences in the mycelial growth rate among the Alternaria isolates were significant $(P<0.001)$. The highest growth rate was obtained for A. kordkuyana (12.0 mm/day), followed by A. dumosa (9.8 $\mathrm{mm} /$ day), A. frumenti $(8.9 \mathrm{~mm} /$ day $)$, A. alternata $(8.1$ $\mathrm{mm} /$ day), A. tenuissima (7.6 mm/day), and A. arborescens $(7.2$ $\mathrm{mm} /$ day) (Fig. 6).

Pathogenicity tests. All Alternaria spp. isolates developed moldy core characterized by the presence of a gray to dark olive-green mycelium with or without sporulation restricted to the carpels (Fig. 2b) in immature and mature apple fruit (Table 6). Reisolations were accomplished for $100 \%$ of the inoculated fruit. Noninoculated fruit remained asymtomatic.

All Alternaria isolates affected $100 \%$ of the inoculated seed, developing a superficial gray to dark olive-green mycelium and rotted $100 \%$ of the immature seed. Isolates of $A$. arborescens, A. tenuissima, and A. kordkuyana and one isolate of A. alternata sporulated on the seed after 5 days at $20^{\circ} \mathrm{C}$.

Independently of the Alternaria spp., none of the isolates were able to cause necrotic lesions on the epidermis and flesh of immature and mature fruit after conidial inoculations, except for a very superficial oxidation and minimal but not measurable necrosis.

Independently of the Alternaria isolates, seed from mature fruit were superficially colonized, developing a gray to dark olive-green mycelium and abundant dark sporulation (Fig. 2c). However, the seed were not rotted, comprising only the testa without evidence of internal seed invasion after 10 days at $20^{\circ} \mathrm{C}$. Significant differences $(P<0.001)$ in the percentage of seed colonization were obtained among isolates and Alternaria spp.

Without exception, all Alternaria isolates were pathogenic on detached apple leaves, developing brown necrotic lesions of 0.4 to $5.7 \mathrm{~mm}$ in diameter, with concentric rings and a chlorotic halo (Fig. 2d), after 5 days at $20^{\circ} \mathrm{C}$. Significant differences $(P<0.001)$ in the lesion diameters were found among isolates and Alternaria spp. Differences in virulence were consistently obtained, with isolates of $A$. tenuissima being the most virulent (mean of $4.3 \mathrm{~mm}$ ), followed by isolates of $A$. alternata (mean of $2.9 \mathrm{~mm}$ ), A. arborescens (mean of $2.5 \mathrm{~mm})$, A. dumosa $(2.1 \mathrm{~mm})$, A. frumenti (mean of $2.0 \mathrm{~mm}$ ), and A. kordkuyana, which was the least virulent isolate $(0.4 \mathrm{~mm})$ (Table 6). Reisolations from the margins of the necrotic lesions were successful from $100 \%$ of the inoculated leaves. The identification of reisolated fungi was confirmed morphologically. Unwounded but inoculated leaves remained asymtomatic.

\section{Discussion}

The analysis of 653 fruit showing moldy core revealed the presence of several genera of filamentous fungi; however, species of Alternaria $(67.7 \%)$ were by far the most commonly and consistently isolated causal agents. Moldy core was only found on apple cultivars having open-sinus fruit but was absent in Granny Smith, a cultivar with closed-sinus fruit.
Based on the results of this study, at least six species of small-spored Alternaria were found: namely, in order of importance, A. tenuissima, A. arborescens, A. alternata, A. dumosa in sect. Alternaria, A. frumenti, in sect. Infectoriae, and A. kordkuyana in sect. Pseudoalternaria These species were identified morphologically and molecularly according to Gannibal and Lawrence (2016), Lawrence et al. (2013), Poursafar et al. (2018), Pryor and Michailides (2002), Simmons (2007), and Zhu and Xiao (2015). The identification of A. kordkuyana should be further studied using additional gene sequences. A concatenated analysis using DNA sequences of ATPase, CAL, and Alt al genes would be advisable. However, DNA sequences of $C A L$ and Alt al genes are not available for A. kordkuyana ex-type.

These Alternaria spp. were isolated alone, or two or more species coexisted in the same fruit. To some extent, the vegetative compatibility exhibited by most species and isolates explained the coexistence of more than one species on the same fruit carpel. Complexes of smallspored Alternaria spp. have been previously identified causing diseases in different fruit crops such as core rot of apple (Serdani et al. 2002), Alternaria leaf blotch and fruit spot (Harteveld et al. 2013; Rotondo et al. 2012), heart rot of pomegranate (Luo et al. 2017; Michailides et al. 2008), Alternaria fruit rot of blueberry (Zhu and Xiao 2015), and Alternaria late blight of pistachio (Pryor and Michailides 2002).

All Alternaria isolates obtained from moldy core of apple were small-spored Alternaria spp. with single conidiophores, catenulate, and muriform conidia (Simmons 2007). There is a general agreement that the identification of Alternaria spp. is taxonomically difficult, particularly the small-spored Alternaria spp., because they share

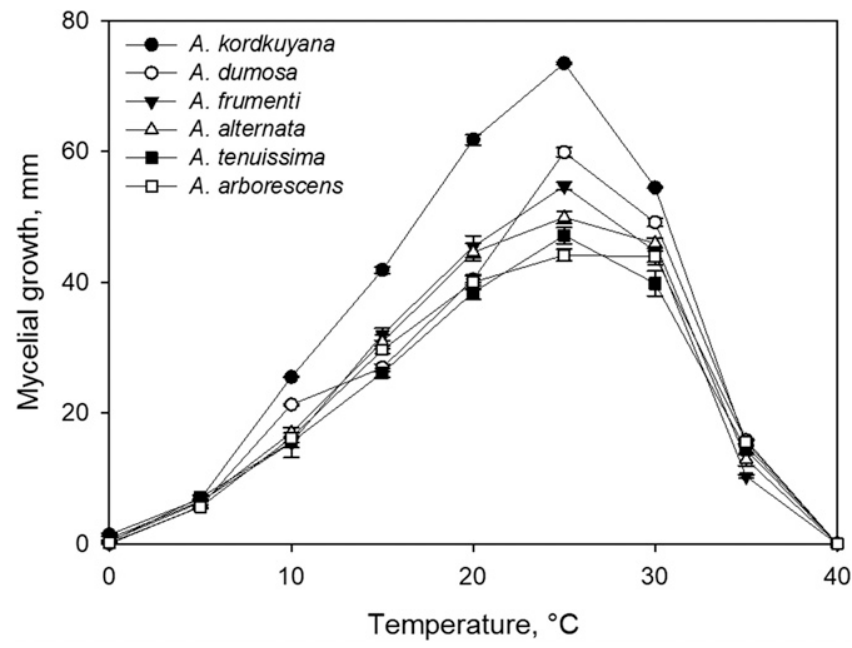

Fig. 5. Effect of temperature on the mean radial mycelial growth of isolates of Alternaria spp. determined after 6 days of incubation on acidified potato dextrose in the dark. Vertical bars $=$ standard errors.

Table 5. Vegetative compatibility tests among isolates of Alternaria spp. obtained from moldy core of apple ${ }^{\mathrm{z}}$

\begin{tabular}{|c|c|c|c|c|c|c|c|c|c|c|c|c|c|c|}
\hline \multicolumn{13}{|c|}{ Isolates } & \multirow[b]{2}{*}{ Isolates } & \multirow[b]{2}{*}{ Species } \\
\hline $7 \mathrm{MC}$ & $12 \mathrm{LS}$ & $16 \mathrm{MC}$ & $8 \mathrm{MC}$ & $13 \mathrm{LS}$ & $38 \mathrm{MC}$ & $28 \mathrm{MC}$ & $2 \mathrm{MC}$ & $37 \mathrm{MC}$ & $34 \mathrm{MC}$ & $11 \mathrm{LS}$ & $15 \mathrm{MC}$ & $18 \mathrm{MC}$ & & \\
\hline $\mathrm{C}$ & $\mathrm{C}$ & $\mathrm{C}$ & $\mathrm{C}$ & $\mathrm{C}$ & $\mathrm{C}$ & $\mathrm{C}$ & $\mathrm{C}$ & $\mathrm{C}$ & $\mathrm{U}$ & $\mathrm{C}$ & $\mathrm{C}$ & $\mathrm{C}$ & $7 \mathrm{MC}$ & Alternaria alternata \\
\hline$\ldots$ & $\mathrm{C}$ & $\mathrm{C}$ & $\mathrm{U}$ & $\mathrm{C}$ & $\mathrm{C}$ & $\mathrm{C}$ & $\mathrm{C}$ & $\mathrm{C}$ & $\mathrm{C}$ & $\mathrm{C}$ & $\mathrm{C}$ & $\mathrm{C}$ & $12 \mathrm{LS}$ & $\ldots$ \\
\hline$\ldots$ & $\ldots$ & $\mathrm{C}$ & $\mathrm{C}$ & $\mathrm{C}$ & $\mathrm{C}$ & $\mathrm{C}$ & $\mathrm{C}$ & $\mathrm{C}$ & $\mathrm{C}$ & $\mathrm{U}$ & $\mathrm{U}$ & $\mathrm{U}$ & $16 \mathrm{MC}$ & $\ldots$ \\
\hline$\ldots$ & $\ldots$ & $\ldots$ & $\mathrm{C}$ & $\mathrm{C}$ & $\mathrm{C}$ & $\mathrm{C}$ & $\mathrm{C}$ & $\mathrm{U}$ & $\mathrm{U}$ & $\mathrm{U}$ & $\mathrm{C}$ & $\mathrm{U}$ & $8 \mathrm{MC}$ & A. arborescens \\
\hline$\ldots$ & $\ldots$ & $\ldots$ & $\ldots$ & $\mathrm{C}$ & $\mathrm{C}$ & $\mathrm{C}$ & $\mathrm{C}$ & $\mathrm{U}$ & I & $\mathrm{U}$ & $\mathrm{C}$ & $\mathrm{C}$ & $13 \mathrm{LS}$ & $\ldots$ \\
\hline$\ldots$ & $\ldots$ & $\ldots$ & $\ldots$ & $\ldots$ & $\mathrm{C}$ & $\mathrm{C}$ & $\mathrm{C}$ & $\mathrm{C}$ & $\mathrm{U}$ & $\mathrm{C}$ & $\mathrm{C}$ & $\mathrm{C}$ & $38 \mathrm{MC}$ & $\ldots$ \\
\hline$\ldots$ & $\ldots$ & $\ldots$ & $\ldots$ & $\ldots$ & $\ldots$ & $\mathrm{C}$ & $\mathrm{C}$ & $\mathrm{C}$ & $\mathrm{U}$ & $\mathrm{C}$ & $\mathrm{C}$ & $\mathrm{C}$ & $28 \mathrm{MC}$ & A. dumosa \\
\hline$\ldots$ & $\ldots$ & $\ldots$ & $\ldots$ & $\ldots$ & $\ldots$ & $\ldots$ & $\mathrm{C}$ & $\mathrm{C}$ & $\mathrm{U}$ & $\mathrm{C}$ & $\mathrm{C}$ & $\mathrm{C}$ & $2 \mathrm{MC}$ & A. frumenti \\
\hline$\ldots$ & $\ldots$ & $\ldots$ & $\ldots$ & $\ldots$ & $\ldots$ & $\ldots$ & $\ldots$ & $\mathrm{C}$ & $\mathrm{C}$ & $\mathrm{U}$ & $\mathrm{C}$ & $\mathrm{C}$ & $37 \mathrm{MC}$ & $\ldots$ \\
\hline$\ldots$ & $\ldots$ & $\ldots$ & $\ldots$ & $\ldots$ & $\ldots$ & $\ldots$ & $\ldots$ & $\ldots$ & $\mathrm{C}$ & $\mathrm{U}$ & $\mathrm{U}$ & $\mathrm{C}$ & $34 \mathrm{MC}$ & A. kordkuyana \\
\hline$\ldots$ & $\ldots$ & $\ldots$ & $\ldots$ & $\ldots$ & $\ldots$ & $\ldots$ & $\ldots$ & $\ldots$ & $\ldots$ & $\mathrm{C}$ & $\mathrm{U}$ & $\mathrm{C}$ & $11 \mathrm{LS}$ & A. tenuissima \\
\hline$\ldots$ & $\ldots$ & $\ldots$ & $\ldots$ & $\ldots$ & $\ldots$ & $\ldots$ & $\ldots$ & $\ldots$ & $\ldots$ & $\ldots$ & $\mathrm{C}$ & $\mathrm{C}$ & $15 \mathrm{MC}$ & $\ldots$ \\
\hline$\ldots$ & $\ldots$ & $\ldots$ & $\ldots$ & $\ldots$ & $\ldots$ & $\ldots$ & $\ldots$ & $\ldots$ & $\ldots$ & $\ldots$ & $\ldots$ & $\mathrm{C}$ & $18 \mathrm{MC}$ & $\ldots$ \\
\hline
\end{tabular}

${ }^{\mathrm{z}}$ Symbols: compatible (C), uncertain (U), and incompatible (I) Alternaria isolates. 
and have overlapping morphological characteristics (Andrew et al. 2009, Serdani et al. 2002). Colonies of isolates in sect. Alternaria varied between gray-green to yellow-green. Isolates of $A$. frumenti and A. kordkuyana, as expected for Alternaria isolates of sect. Infectoriae and Pseudoalternaria, developed white and distinctive colonies on DRYES medium (Andersen et al. 2002; Lawrence et al. 2014; Poursafar et al. 2018).

In contrast to previous works (Rang et al. 2002; Sun and Huang 2017; Zheng et al. 2015), the phylogenetic analysis of the partial coding sequence of the HIS gene was inadequate to distinguish isolates of Alternaria spp. from moldy core of apple in this study. Similarly to previous studies (Lawrence et al. 2013, 2016; Luo et al. 2017; Zheng et al. 2015), the MP analysis of the rDNA ITS sequence allowed us to clearly delimit the small-spored species of Alternaria within sections Alternaria, Infectoriae, and Pseudoalternaria. However, it was not informative enough to segregate the species within each section.

Phylogenetic analysis using the ATPase, CAL, and Alt al genes has been proposed to differentiate species of Alternaria in previous works (Lawrence et al. 2013; Zhu and Xiao 2015). In the present study, the Alt al gene provides sufficient information to clearly distinguish Alternaria isolates in sect. Pseudoalternaria from sect. Alternaria and sect. Infectoriae. The $C A L$ gene allowed the differentiation of A. arborescens, A. dumosa, and isolates of Alternaria sect. Infectoriae and sect. Pseudoalternaria, placing them in four separate clusters, but the information provided by this gene was not sufficient to distinguish A. tenuissima and A. alternata as separate species. These last two species were clearly separated using the ATPase gene. However, in agreement with Zhu and Xiao (2015), A. destruens was clustered into the same group with $A$. alternata isolates from apple and the reference isolates of $A$. alternata but $A$. alternata and A. destruens could be differentiated by their sporulation patterns, which widely differ.

In Greece, Ntasiou et al. (2015) determined the presence of A.tenuissima and $A$. arborescens as the cause of core rot of apple. Gao et al. (2013) reported an association of A. alternata, A. arborescens,
A. infectoria, and A. tenuissima with moldy core in Fuji apple in China. Similarly, Serdani et al. (2002), studying the Alternaria spp. associated with dry core rot of apple in South Africa, demonstrated the presence of $A$. arborescens, $A$. infectoria, and A. tenuissima. However, isolates of A. infectoria from China and South Africa were not pathogenic. In contrast to results from Gao et al. (2013) and Serdani et al. (2002), isolates of A. frumenti in sect. Infectoriae from Chile were pathogenic on apple fruit and leaves. Additionally, in this study, two other pathogenic Alternaria spp., A. dumosa and A. kordkuyana, were found.

Independently of the Alternaria spp., all isolates were pathogenic, colonizing the carpels and rotting seed from immature fruit, but the seed from mature fruit were only surface colonized, without affecting the seed internally. All isolates induced small necrotic lesions on detached wounded leaves but were unable to infect nonwounded leaves, suggesting that leaf injuries are needed for infection under field conditions. However, significant $(P<0.001)$ differences in lesion diameter were obtained, suggesting differences in virulence among Alternaria isolates, with A. tenuissima being the most virulent species, followed by A. alternata, A. arborescens, A. dumosa, A. frumenti, and A. kordkuyana. Independently of the virulence on leaf assays and the lack of pathogenicity on immature and mature fruit, all Alternaria spp. showed a high capacity to colonize the carpels of both immature and mature fruit, which is the main concern regarding moldy core of apple fruit. Furthermore, differences in virulence between Alternaria spp. have been detected on other hosts. For example, on blueberry and pistachio, isolates of A. infectoria were less virulent than A. alternata, A. arborescens, and A. tenuissima (Pryor and Michailides 2002; Zhu and Xiao 2015).

Alternaria isolates were not able to produce fruit rot lesions in this study, as was reported previously for some isolates of A. alternata, A. arborescens, and A. tenuissima (Harteveld et al. 2014; Rotondo et al. 2012). These differences in the pathogenic capacities suggest the presence of different pathotypes. Nevertheless, differences in the susceptibility of apple cultivars used in the pathogenicity tests can also

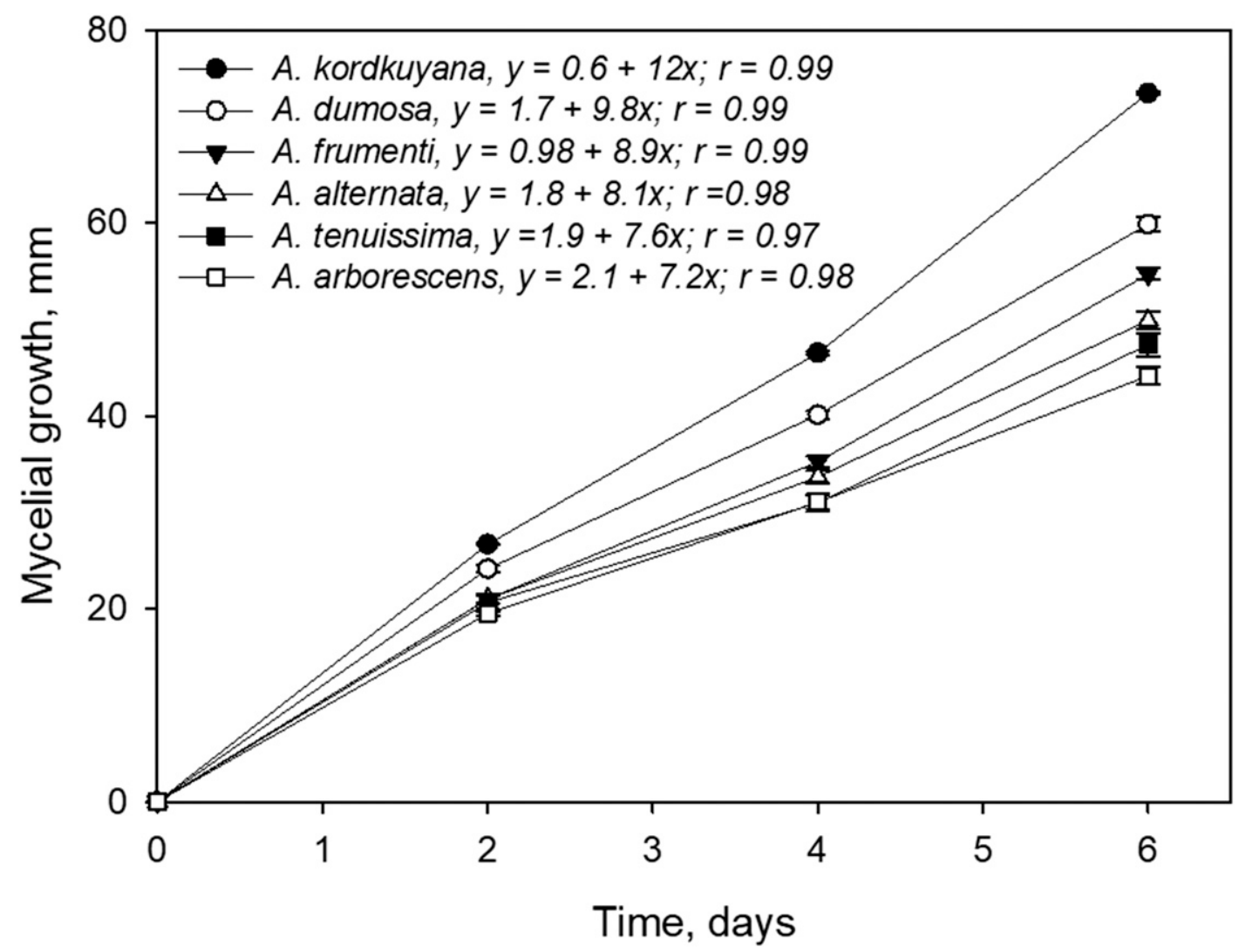

Fig. 6. Mycelial growth rate of isolates Alternaria spp. estimated on acidified potato dextrose in the dark at $25^{\circ} \mathrm{C}$. Vertical bars $=$ standard errors. 
explain these results. Large differences in susceptibility have been reported; Golden Delicious was very susceptible, Top Red was moderately resistant, and Jonathan was resistant (Gur et al. 2017). In addition, the inoculated tissue should be considered, because it has been shown that the mesoderm close to the skin is highly resistant to Alternaria rot, increasing in susceptibility toward the carpels (Gur et al. 2017). Interestingly, no evidence was obtained in this study of $A$. mali, which has been associated mainly with fruit rot of apple (Gur et al. 2017; Harteveld et al. 2013; Rotondo et al. 2012).

All of the reference isolates obtained from necrotic leaf spot of apple were equally able to colonize carpels internally, developing a cottony gray to olive-green mycelium that characterized apple moldy core. Therefore, there was no evidence for apple tissue specificity among isolates of Alternaria spp. attacking apple. Similar to findings by Rang et al. (2002), our results suggested that moldy core resulted from opportunistic and favorable conditions rather than true specific pathological abilities exhibited by the isolates of Alternaria spp.

Moldy core prevalence between 4 and $46 \%$ was estimated in this study, reinforcing the economic importance of moldy core in the Chilean apple industry. As has been reported in other appleproducing countries (Ellis and Barrat 1983, Kupferman 1992; Miller 1959; Reuveni 2006; Serdani et al. 1998), moldy core has been associated with the open-sinus condition of Delicious cultivars. In this study, 40 and 53\% of Oregon Spur and Red Chief apple with an open sinus were very susceptible, showing the highest moldy core prevalence (16 to $46 \%$ ). In the present study, Fuji (Red Delicious $\times$ Ralls Janet) had a high proportion of open-sinus fruit at harvest (42\%).
However, a relatively low $(<13 \%)$ proportion of moldy core was determined. This finding can be explained by factors other than the sinus condition of the fruit (Shtienberg 2012). Differences in the mesoderm and locule sensitivity of each apple cultivar to colonization by moldy core fungi could also explain the substantial variation in prevalence obtained among open-sinus apple cultivars in this study (Niem et al. 2007)

The apparent resistance of Granny Smith apple to moldy core appeared to be associated with the closed-sinus condition characterizing Granny Smith fruit (Serdani et al. 1998).

In summary, this study demonstrates that moldy core of apple is caused by many small-spored Alternaria spp. The most frequently isolated species was A. tenuissima, which was virulent on apple leaf assays and showed a high capacity to colonize apple carpels. However, A. tenuissima and the other Alternaria spp. show no capacity to cause lesion on the epidermis and flesh of apple fruit. This species coexisted with one or more Alternaria spp. This is the first report of A. arborescens, A. dumosa, A. frumenti, A. tenuissima, and A. kordkuyana associated with moldy core of apple in Chile and the first report of A. dumosa, A. frumenti, and A. kordkuyana causing moldy core of apple worldwide. The results of this study do not exclude the possibility that other species may be involved in the Alternaria complex associated with moldy core of apple. The presence of different species of Alternaria may have implications to consider when establishing control strategies, because Alternaria spp. may have different sensitivities to fungicides. More information on moldy core epidemiology and sensitivity to fungicides of Alternaria spp. is needed in order to implement successful control strategies.

Table 6. Pathogenicity of Alternaria spp. isolates on fruit and leaves of Red Chief apple, producing colonization of carpels and seed and causing necrotic lesions on leaves $\mathrm{x}$

\begin{tabular}{|c|c|c|c|c|c|c|c|}
\hline \multirow[b]{2}{*}{ Isolates } & \multicolumn{3}{|c|}{ Immature fruit ${ }^{y}$} & \multicolumn{3}{|c|}{ Mature fruit ${ }^{y}$} & \multirow{2}{*}{$\frac{\text { Leaves }^{\mathrm{z}}}{\text { NL }(\mathrm{mm})}$} \\
\hline & $\mathrm{CM}(\%)$ & SR (\%) & $\overline{\mathrm{DR}}(\mathbf{m m})$ & $\mathrm{CM}(\%)$ & SM (\%) & DR $(\mathbf{m m})$ & \\
\hline \multicolumn{8}{|c|}{ Alternaria alternata } \\
\hline $7 \mathrm{MC}$ & $85 \mathrm{a}-\mathrm{d}$ & 100 & 0.0 & $100 \mathrm{~ns}$ & $90 \mathrm{~b}$ & 0.0 & $4.7 \mathrm{a}-\mathrm{c}$ \\
\hline $12 \mathrm{LS}$ & $65 \mathrm{~d}$ & 100 & 0.0 & 70 & $95 \mathrm{ab}$ & 0.0 & $2.5 \mathrm{c}-\mathrm{g}$ \\
\hline $16 \mathrm{MC}$ & $80 \mathrm{a}-\mathrm{d}$ & 100 & 0.0 & 80 & $90 \mathrm{~b}$ & 0.0 & $1.3 \mathrm{~g}$ \\
\hline $30 \mathrm{MC}$ & $95 \mathrm{ab}$ & 100 & 0.0 & 90 & $100 \mathrm{a}$ & 0.0 & $4.0 \mathrm{a}-\mathrm{d}$ \\
\hline $36 \mathrm{MC}$ & $75 \mathrm{~cd}$ & 100 & 0.0 & 80 & $100 \mathrm{a}$ & 0.0 & $2.0 \mathrm{~d}-\mathrm{g}$ \\
\hline Mean & 80 & 100 & 0.0 & 84 & 95 & 0.0 & 2.9 \\
\hline \multicolumn{8}{|c|}{ A. arborescens } \\
\hline $8 \mathrm{MC}$ & $80 b-d$ & 100 & 0.0 & 100 & $100 \mathrm{a}$ & 0.0 & $2.9 \mathrm{~b}-\mathrm{f}$ \\
\hline 13LS & $85 \mathrm{a}-\mathrm{d}$ & 100 & 0.0 & 90 & $100 \mathrm{a}$ & 0.0 & $2.8 \mathrm{~b}-\mathrm{f}$ \\
\hline $19 \mathrm{MC}$ & $85 a-d$ & 100 & 0.0 & 90 & $100 \mathrm{a}$ & 0.0 & $3.0 \mathrm{a}-\mathrm{e}$ \\
\hline $38 \mathrm{MC}$ & $95 \mathrm{ab}$ & 100 & 0.0 & 95 & $100 \mathrm{a}$ & 0.0 & $1.9 \mathrm{~d}-\mathrm{g}$ \\
\hline $40 \mathrm{MC}$ & $90 a-c$ & 100 & 0.0 & 90 & $100 \mathrm{a}$ & 0.0 & $2.1 \mathrm{e}-\mathrm{g}$ \\
\hline Mean & 87 & 100 & 0.0 & 93 & 100 & 0.0 & 2.5 \\
\hline \multicolumn{8}{|c|}{ A. dumosa } \\
\hline $28 \mathrm{MC}$ & $100 \mathrm{a}$ & 100 & 0.0 & 95 & $100 \mathrm{a}$ & 0.0 & $2.1 \mathrm{e}-\mathrm{g}$ \\
\hline \multicolumn{8}{|c|}{ A. frumenti } \\
\hline $2 \mathrm{MC}$ & $80 \mathrm{a}-\mathrm{d}$ & 100 & 0.0 & 85 & $45 \mathrm{c}$ & 0.0 & $2.2 \mathrm{c}-\mathrm{g}$ \\
\hline $37 \mathrm{MC}$ & $90 \mathrm{a}-\mathrm{c}$ & 100 & 0.0 & 80 & $50 \mathrm{c}$ & 0.0 & $1.5 \mathrm{fg}$ \\
\hline Mean & 95 & 100 & 0.0 & 83 & 48 & 0.0 & 2.0 \\
\hline \multicolumn{8}{|c|}{ A. kordkuyana } \\
\hline $34 \mathrm{MC}$ & $95 \mathrm{ab}$ & 100 & 0.0 & 95 & $90 \mathrm{~b}$ & 0.0 & $0.4 \mathrm{~h}$ \\
\hline \multicolumn{8}{|c|}{ A. tenuissima } \\
\hline $11 \mathrm{LS}$ & $95 \mathrm{ab}$ & 100 & 0.0 & 95 & $100 \mathrm{a}$ & 0.0 & $5.7 \mathrm{a}$ \\
\hline $15 \mathrm{MC}$ & $100 \mathrm{a}$ & 100 & 0.0 & 95 & $100 \mathrm{a}$ & 0.0 & $3.4 \mathrm{a}-\mathrm{e}$ \\
\hline $18 \mathrm{MC}$ & $90 \mathrm{a}-\mathrm{c}$ & 100 & 0.0 & 85 & $100 \mathrm{a}$ & 0.0 & $4.9 \mathrm{ab}$ \\
\hline $33 \mathrm{MC}$ & $95 \mathrm{ab}$ & 100 & 0.0 & 90 & $100 \mathrm{a}$ & 0.0 & $5.3 \mathrm{ab}$ \\
\hline $42 \mathrm{MC}$ & $95 \mathrm{ab}$ & 100 & 0.0 & 90 & $100 \mathrm{a}$ & 0.0 & $2.3 \mathrm{~d}-\mathrm{g}$ \\
\hline Mean & 95 & 100 & 0.0 & 91 & 100 & 0.0 & 4.3 \\
\hline
\end{tabular}

x Abbreviations: $\mathrm{CM}=$ carpel moldy, $\mathrm{SR}=$ seed rot, $\mathrm{DR}=$ dry rot, $\mathrm{SM}=$ seed moldy, and NL= necrotic lesions. Noninoculated controls remained symptomless and those data were excluded from the statistical analysis. Means of four replicates followed by the same letter in each column did not differ significantly, separated according to the Fisher's least significant difference test $(P<0.05)$; ns $=$ not significant at $P=0.05$.

${ }^{y}$ Five carpels per fruit $(n=4)$ and five seeds per replicate $(n=4)$ were inoculated with a conidial suspension $\left(10^{6}\right.$ conidia/ml) incubated in humid chambers at $20^{\circ} \mathrm{C}$ for 5 days for immature fruit and for 10 days for mature fruit. Data percentages were arcsine $\sqrt{(x / 100)}$ transformed but nontransformed data are presented.

${ }^{\mathrm{z}}$ Leaves were inoculated with conidial suspension $\left(10^{6}\right.$ conidia/ml), and lesion diameters were determined after 4 days at $20^{\circ} \mathrm{C}$ in humid chambers. Data were transformed to $\operatorname{Ln}(x+1)$ prior to analysis but nontransformed data are presented. 


\section{Acknowledgments}

We thank P. Naranjo, G. A. Díaz, E. E. Ferrada, and B. Puebla for their technical support; and the commercial packinghouses of Copefrut, DOLE Chile, Frusan, Magna Trading, and Verfrut for providing the fruit that were used in this study.

\section{Literature Cited}

Andersen, B., Krøger, E. G., and Roberts, R. 2002. Chemical and morphological segregation of Alternaria arborescens, A. infectoria and A. tenuissima speciesgroups. Mycol. Res. 106:170-182.

Andrew, M., Peever, T. L., and Pryor, B. M. 2009. An expanded multilocus phylogeny does not resolve morphological species within the small-spored Alternaria species complex. Mycologia 101:95-109.

Elfar, K., Torres, R., Díaz, G. A., and Latorre, B. A. 2013. Characterization of Diaporthe australafricana and Diaporthe spp. associated with stem canker of blueberry in Chile. Plant Dis. 97:1042-1050.

Elfar, K., Zoffoli, J. P., and Latorre, B. A. 2018. Occurrence of Alternaria blotch associated with Alternaria alternata, A. arborescens, A. infectoria and A. tenuissima on apples in Chile. Plant Dis. 102:1668.

Ellis, M. A., and Barrat, J. G. 1983. Colonization of Delicious apple fruits by Alternaria spp. and effect of fungicide sprays on moldy-core. Plant Dis. 67: 150-152.

Filatov, D. A. 2002. ProSeq: A software for preparation and evolutionary analysis of DNA sequence data sets. Mol. Ecol. Notes 2:621-624.

Frisvad, J. C. 1983. A selective and indicative medium for groups of Penicillium viridicatum producing different mycotoxins on cereals. J. Appl. Microbiol. 54:409-416.

Gannibal, P. B., and Lawrence, D. P. 2016. Distribution of Alternaria species among sections. 3. Sections Infectoriae and Pseudoalternaria. Mycotaxon 131:781-790.

Gao, L. L., Zhang, Q., Sun, X. Y., Jiang, L., Zhang, R., Sun, G. Y., Zha, Y. L., and Biggs, A. R. 2013. Etiology of moldy core, core browning, and core rot of Fuji apple in China. Plant Dis. 97:510-516.

Glass, N. L., and Donaldson, G. C. 1995. Development of primer sets designed for use with the PCR to amplify conserved genes from filamentous ascomycetes. Appl. Environ. Microbiol. 61:1323-1330.

Gur, L., Reuveni, M., and Cohen, Y. 2017. Occurrence and etiology of Alternaria leaf blotch and fruit spot of apple caused by Alternaria alternata f. sp. mali on cv. Pink Lady in Israel. Eur. J. Plant Pathol. 147:695-708.

Harteveld, D. O. C., Akinsanmi, O. A., and Drenth, A. 2013. Multiple Alternaria species groups are associated with leaf blotch and fruit spot diseases of apple in Australia. Plant Pathol. 62:289-297.

Harteveld, D. O. C., Akinsanmi, O. A., and Drenth, A. 2014. Pathogenic variation of Alternaria species associated with leaf blotch and fruit spot of apple in Australia. Eur. J. Plant Pathol. 139:789-799.

Hong, S. G., Cramer, R. A., Lawrence, C. B., and Pryor, B. M. 2005. Alt a1 allergen homologs from Alternaria and related taxa: Analysis of phylogenetic content and secondary structure. Fungal Genet. Biol. 42:119-129.

Kumar, S., Stecher, G., and Tamura, K. 2016. Molecular evolutionary genetics analysis version 7.0 for bigger datasets. Mol. Biol. Evol. 33:1870-1874.

Kupferman, E. M. 1992. Maturity and storage of apple varieties new to Washington State. Tree Fruit Postharvest J. 3:9-15.

Larkin, M. A., Blackshields, G., Brown, N. P., Chenna, R., McGettigan, P. A., McWilliam, H., Valentin, F., Wallace, I. M., Wilm, A., Lopez, R., Thompson, J. D., Gibson, T. J., and Higgins, D. G. 2007. Clustal W and Clustal X version 2.0. Bioinformatics 23:2947-2948.

Latorre, B. A. 1983. Moho negro del corazón de la manzana. Rev. Frutic. 4:23-24.

Latorre, B. A. 1986. El corazón mohoso de la manzana: Un problema asociado a cavidades calicinales abiertas. Rev. Frutic. 7:120.

Lawrence, D. P., Gannibal, P. B., Dugan, F. M., and Pryor, B. M. 2014. Characterization of Alternaria isolates from the infectoria species-group and a new taxon from Arrhenatherum, Pseudoalternaria arrhenatheria sp. nov. Mycol. Prog. 13:257-276.

Lawrence, D. P., Gannibal, P. B., Peever, T. L., and Pryor, B. M. 2013. The sections of Alternaria: Formalizing species-groups concepts. Mycologia 105: 530-546.

Lawrence, D. P., Rotondo, F., and Gannibal, P. B. 2016. Biodiversity and taxonomy of the pleomorphic genus Alternaria. Mycol. Prog. 15:3-25.

Luo, Y., Hou, L., Förster, H., Pryor, B., and Adaskaveg, J. E. 2017. Identification of Alternaria species causing fruit tot of pomegranates in California. Plant Dis. 101:421-427.

McLeod, A. 2014. Moldy core and core rots. Pages 40-41 in: Compendium of Apple and Pear Diseases and Pests, 2nd ed. T. B. Sutton, H. S. Aldwinckle, A. M. Agnello, and J. F. Walgenbach, eds. American Phytopathological Society, St Paul, MN.
Michailides, T., Morgan, D., Quist, M., and Reyes, H. 2008. Infection of pomegranate by Alternaria spp. causing black heart. (Abstr.) Phytopathology 98:S105.

Miller, P. M. 1959. Open calyx tubes as a factor contributing to carpel discoloration and decay of apples. Phytopathology 49:520-523.

Morales, M. A. 1986. Alteraciones del corazón de la manzana. Rev. Frutic. 7:7-10.

Niem, J., Miyara, I., Ettedgui, Y., Reuveni, M., Flaishman, M., and Prusky, D. 2007. Core rot development in red delicious apples is affected by susceptibility of the seed locule to Alternaria alternata colonization. Phytopathology 97:1415-1421.

Ntasiou, P., Myresiotis, C., Konstantinou, S., Papadopoulou-Mourkidou, E., and Karaoglanidis, G. S. 2015. Identification, characterization and mycotoxigenic ability of Alternaria spp. causing core rot of apple fruit in Greece. Int. J. Food Microbiol. 197:22-29.

Pinilla, B., Trombert, Y., and Alvarez, M. 1996. Efecto de la aplicación de fungicidas en la incidencia de corazón mohoso en manzanas almacenadas en frío. Agric. Téc. (Chillán) 56:155-162.

Poursafar, A., Ghosta, Y., Orina, A. S., Gannibal, P. B., Javan-Nikkhah, M., and Lawrence, D. P. 2018. Taxonomic study on Alternaria sections Infectoriae and Pseudoalternaria associated with black (sooty) head mold of wheat and barley in Iran. Mycol. Prog. 17:343-356.

Pryor, B. M., and Gilbertson, R. L. 2000. Molecular phylogenetic relationships amongst Alternaria species and related fungi based upon analysis of nuclear ITS and mt SSU rDNA sequences. Mycol. Res. 104:1312-1321.

Pryor, B. M., and Michailides, T. J. 2002. Morphological, pathogenic, and molecular characterization of Alternaria isolates associated with Alternaria late blight of pistachio. Phytopathology 92:406-416.

Rang, J.-C., Crous, P. W., Mchau, G. R. A., Serdani, M., and Song, S.-M. 2002 Phylogenetic analysis of Alternaria spp. associated with apple core rot and citrus black rot in South Africa. Mycol. Res. 106:1151-1162.

Reuveni, M. 2006. Inhibition of germination and growth of Alternaria alternata and mouldy-core development in Red Delicious apple fruit by bromuconazole and sygnum. Crop Prot. 25:253-258

Reuveni, M., Sheglov, D., Sheglov, N., Ben-Arie, R., and Prusky, D. 2002 Sensitivity of Red Delicious apple fruit at various phenologic stages to infection by Alternaria alternata and moldy-core control. Eur. J. Plant Pathol. 108:421-427.

Rotondo, F., Collina, M., Brunelli, A., and Pryor, B. M. 2012. Comparison of Alternaria spp. collected in Italy from apple with A. mali and other AM-toxin producing strains. Phytopathology 102:1130-1142.

Serdani, M., Crous, P. W., Holz, G., and Petrini, O. 1998. Endophytic fung associated with core rot of apples in South Africa, with specific reference to Alternaria species. Sydowia 50:257-271.

Serdani, M., Kang, J. C., Peever, T. L., Andersen, B., and Crous, P. W. 2002. Characterization of Alternaria species groups associated with core rot of apples in South Africa. Mycol. Res. 106:561-569.

Shtienberg, D. 2012. Effects of host physiology on the development of core rot caused by Alternaria alternata, in Red Delicious apples. Phytopathology 102:769-778.

Simmons, E. G. 2007. Alternaria: An Identification Manual. CBS Funga Biodiversity Centre, Utrecht, The Netherlands.

Spotts, R. A., Holmes, R. J., and Washington, W. S. 1988. Factors affecting wet core rot of apples. Australas. Plant Pathol. 17:53-57.

Sun, X. M., and Huang, J. G. 2017. First Report of Alternaria tenuissima causing red leaf spot disease on Paeonia lactiflora in China. Plant Dis. 101:1322.

Swofford, D. L. 2002. PAUP*: Phylogenetic Analysis Using Parsimony. (*and Other Methods), version 4.0b10. Sinauer Associates, Sunderland, MA.

van der Waals, J. E., Korsten, L., and Slippers, B. 2004. Genetic diversity among Alternaria solani isolates from potatoes in South Africa. Plant Dis. 88:959-964.

White, T. J., Bruns, T., Lee, S., and Taylor, J. 1990. Amplification and direct sequencing of fungal ribosomal RNA genes for phylogenetics. Pages 315-322 in: PCR, A Guide to Methods and Applications. M. A. Innis, D. H Gelfand, J. J. Snisky, and T. J. White, eds. Academic Press, San Diego, CA.

Woudenberg, J. H. C., Groenewald, J. Z., Binder, M., and Crous, P. W. 2013. Alternaria redefined. Stud. Mycol. 75:171-212.

Woudenberg, J. H. C., Seid, M. F., Groenewald, J. Z., de Vries, M., Stielow, J. B., Thomma, B. P. H. J., and Crous, P. W. 2015. Alternaria section Alternaria: Species, formae speciales or pathotypes? Stud. Mycol. 82:1-21.

Zheng, H. H., Zhao, J., Wang, T. Y., and Wu, X. H. 2015. Characterization of Alternaria species associated with potato foliar diseases in China. Plant Pathol. 64:425-433.

Zhu, X. Q., and Xiao, C. L. 2015. Phylogenetic, morphological and pathogenic characterization of Alternaria species associated with fruit rot of blueberry in California. Plant Dis. 105:1555-1567. 